\title{
Spatial variability in iron nutritional status of large diatoms in the Sea of Okhotsk with special reference to the Amur River discharge
}

\author{
K. Suzuki ${ }^{1,2}$, A. Hattori-Saito ${ }^{1}$, Y. Sekiguchi ${ }^{1}$, J. Nishioka ${ }^{3}$, M. Shigemitsu ${ }^{1}$, T. Isada ${ }^{1}$, H. Liu ${ }^{4}$, and R. M. L. McKay ${ }^{5}$ \\ ${ }^{1}$ Faculty of Environmental Earth Science/Graduate School of Environmental Science, Hokkaido University, North 10 West 5 , \\ Kita-ku, Sapporo 060-0810, Japan \\ ${ }^{2}$ CREST, Japan Science and Technology, North 10 West 5, Kita-ku, Sapporo 060-0810, Japan \\ ${ }^{3}$ Institute of Low Temperature Science, Hokkaido University, North 19 West 8, Kita-ku, Sapporo 060-0810, Japan \\ ${ }^{4}$ Department of Biology, Hong Kong University of Science and Technology, Clear Water Bay, Hong Kong \\ ${ }^{5}$ Department of Biological Sciences, Bowling Green State University, Bowling Green, Ohio 43403, USA
}

Correspondence to: K. Suzuki (kojis@ees.hokudai.ac.jp)

Received: 19 November 2013 - Published in Biogeosciences Discuss.: 8 January 2014

Revised: 17 March 2014 - Accepted: 22 March 2014 - Published: 7 May 2014

\begin{abstract}
The Sea of Okhotsk is known as one of the most biologically productive regions among the world's oceans, and its productivity is supported in part by the discharge of iron (Fe)-rich water from the Amur River. However, little is known about the effect of riverine-derived $\mathrm{Fe}$ input on the physiology of the large diatoms which often flourish in surface waters of the productive continental shelf region. We conducted diatom-specific immunochemical ferredoxin (Fd) and flavodoxin (Fld) assays in order to investigate the spatial variability of Fe nutritional status in the microplanktonsized $(20-200 \mu \mathrm{m}$; hereafter micro-sized) diatoms. The Fd index, defined as the proportion of $\mathrm{Fd}$ to the sum of $\mathrm{Fd}$ plus Fld accumulations in the cells, was used to assess their Fe nutritional status. Additionally, active chlorophyll fluorescence measurements using pulse-amplitude-modulated (PAM) fluorometry were carried out to obtain the maximum photochemical quantum efficiency $\left(F_{\mathrm{v}} / F_{\mathrm{m}}\right)$ of photosystem II for the total micro-sized phytoplankton assemblages including diatoms. During our observations in the summer of 2006, the micro-sized diatoms were relatively abundant ( $>10 \mu \mathrm{g} \mathrm{C} \mathrm{L}^{-1}$ ) in the neritic region, and formed a massive bloom in Sakhalin Bay near the mouth of the Amur River. Values of the $\mathrm{Fd}$ index and $F_{\mathrm{v}} / F_{\mathrm{m}}$ were high ( $>0.9$ and $>0.65$, respectively) near the river mouth, indicating that $\mathrm{Fe}$ was sufficient for growth of the diatoms. However, in oceanic waters of the Sea of Okhotsk, the diatom Fd index declined as cellular Fld accumulation increased. These results suggest that there was a distinct gradient in Fe nutritional status in
\end{abstract}

the micro-sized diatoms from near the Amur River mouth to open waters in the Sea of Okhotsk. A significant correlation between dissolved $\mathrm{Fe}$ (D-Fe) concentration and the Fd index was found in waters off Sakhalin Island, indicating that D-Fe was a key factor for the photophysiology of this diatom size class. In the vicinity of the Kuril Islands between the Sea of Okhotsk and the Pacific Ocean, micro-sized diatoms only accumulated Fld (i.e., Fd index $=0$ ), despite strong vertical mixing consistent with elevated surface D-Fe levels $(>0.4 \mathrm{nM})$. Since higher Fe quotas are generally required for diatoms growing under low-light conditions, the micro-sized diatoms off the Kuril Islands possibly encountered $\mathrm{Fe}$ and light co-limitations. The differential expressions of Fd and Fld in micro-sized diatoms helped us to understand how these organisms respond to Fe availability in the Sea of Okhotsk in connection with the Amur River discharge.

\section{Introduction}

Iron $(\mathrm{Fe})$ plays an important role in metabolic processes such as photosynthesis, respiration, and nitrogen assimilation for marine phytoplankton (Twining and Baines, 2013; Behrenfeld and Milligan, 2013). Over the last two decades, much attention has been focused on the availability of $\mathrm{Fe}$ to phytoplankton in the open ocean, especially high-nutrient, lowchlorophyll (HNLC) waters such as the Southern Ocean, the subarctic Pacific, and the eastern equatorial Pacific (de Baar 
et al., 2005; Boyd et al., 2007). However, it has become evident that Fe limitation for phytoplankton growth can occur not only in offshore waters, but also in coastal upwelling regions and marginal seas (e.g., Bruland et al., 2001; Hutchins et al., 2002; Aguilar-Islas et al., 2007; Sedwick et al., 2011; Gerringa et al., 2012). In coastal waters, both riverine and sedimentary Fe can cause pronounced near-shore to offshore gradients in dissolved $\mathrm{Fe}$ concentrations. Riverine $\mathrm{Fe}$ is an important supply term at source, but much of the incoming $\mathrm{Fe}$ is rapidly scavenged onto sinking particles in estuaries (Boyle et al., 1977; Boyd and Ellwood, 2010). The removal of Fe can vary depending on the origin and chemical structure of the Fe provided into the coastal waters, because $\mathrm{Fe}$ complexes with organic ligands may act to protect $\mathrm{Fe}$ from removal by scavenging (Buck et al., 2007). Therefore, to determine to what extent $\mathrm{Fe}$ is available for phytoplankton growth in such regions is crucial (Chase et al., 2007), because this in turn can control the structure and dynamics of lower trophic level processes in the near-shore environment. Among the phytoplankton, it is well known that large diatoms often flourish in coastal waters (e.g., Orlova et al., 2004; Suzuki et al., 2011). Such large diatoms tend to be grazed by large zooplankton, resulting in shorter, simpler food webs that may result in more efficient matter and energy transfer (Ryther, 1969). However, the growth of large diatoms is expected to be more sensitive to Fe deficit than that of small cells due to their small cell surface to volume ratios (Sunda and Huntsman, 1997; Timmermans et al., 2004; Sarthou et al., 2005). To our knowledge, no literature has been published on spatiotemporal variability in the $\mathrm{Fe} n u-$ tritional status of large diatoms in coastal or marginal seas.

The Sea of Okhotsk, one of the marginal seas of the western North Pacific, is known as one of the most biologically productive regions among the world's oceans, especially along its continental shelf (Sorokin and Sorokin, 1999; Isada et al., 2013). Diatoms account for much of the production in these waters with growth supported by sea-ice melting during spring and the Amur River discharge from summer to fall (Nakatsuka et al., 2004). In winter, the Sea of Okhotsk is covered with sea ice and is the most southern extension of the region of seasonal ice formation (Kimura and Wakatsuchi, 2000). From spring to summer, increases in irradiance and temperature lead to the melting of sea ice, resulting in the formation of a pycnocline in surface waters of the Sea of the Okhotsk. Also impacting the region is the Amur River, the longest river $(4350 \mathrm{~km})$ in the far eastern region of Russia, supplying not only large volumes of freshwater (Ogi et al., 2001), but also high levels of nutrients including $\mathrm{Fe}$ and organic matter into the Sea of Okhotsk via the southwardflowing East Sakhalin Current which runs along the eastern coast of Sakhalin Island (Nishioka et al., 2007; Andreev and Pavlova, 2009; Nagao et al., 2010; Takao et al., 2014). According to Nagao et al. (2010), Amur River water contains ca. $4 \mu \mathrm{M}$ of dissolved $\mathrm{Fe}$ and its annual flux from the river to the Sea of Okhotsk is estimated as $(1.1 \pm 0.7) \times 10^{11} \mathrm{~g} \mathrm{yr}^{-1}$. The dissolved Fe level is four orders of magnitude higher than that typically reported for low-Fe HNLC waters $(<0.2 \mathrm{nM}$; Johnson et al., 1997) and the annual flux corresponds to ca. $10 \%$ of the global riverine value (Raiswell, 2006). The changes in physical and chemical conditions from spring to summer allow phytoplankton to remain in the sunlit surface layer and form massive diatom blooms until nutrients are depleted in the Sea of Okhotsk (Sorokin and Sorokin, 1999, 2002). Thus, the Sea of Okhotsk is an excellent natural laboratory to investigate the importance of riverine $\mathrm{Fe}$ to large diatoms.

Regarding the Fe dynamics in the study area, Nishioka et al. $(2007,2011,2013,2014)$ demonstrated the importance of the transport of intermediate dense shelf water (DSW) from the Sea of Okhotsk to the North Pacific via the Kuril Straits, mainly through the Bussol' Strait, the deepest channel of the Kuril Islands. In winter, large amounts of sea ice are produced along the Siberian coast on the northwestern continental shelf of the Sea of Okhotsk. The sea-ice formation generates a large volume of Fe-containing brine, which subsequently settles to the bottom of the northwestern continental shelf along the Siberian coast to form the DSW formation (Martin et al., 1998). The high levels of Fe derived from the Amur River should contribute significantly to the contents of $\mathrm{Fe}$ in the brine. Additionally, large amounts of dissolved and particulate $\mathrm{Fe}$ are introduced to the DSW by re-suspension of sediments (Nishioka et al., 2014). Since the density of DSW is relatively low $(26.8-27.0 \sigma \theta)$, it tends to penetrate the upper part (250-450 m) of the Okhotsk Sea intermediate water (OSIW). The OSIW flows southward along the east coast of Sakhalin Island and is transported to the Kuril Straits. Because the tidal flow generates intense vertical mixing around the Bussol' Strait (Yagi and Yasuda, 2012), the mixing transports the deep water with high-Fe content to the surface (Nishioka et al., 2007, 2013). Although these processes should enhance the availability of Fe for phytoplankton growth, little knowledge is available on this issue.

In this study, we report on the status of $\mathrm{Fe}$ nutrition in microplankton-sized (i.e., 20-200 $\mu \mathrm{m}$, hereafter micro-sized) diatoms with reference to dissolved Fe levels in surface waters of the western part of the Sea of Okhotsk during late summer 2006. Fe deficiency in the large diatoms was assessed by determining the ferredoxin (Fd) index, which is defined as the proportion of Fd to the sum of Fd plus flavodoxin (Fld) accumulations (Doucette et al., 1996). Under Fe deficient conditions, the Fe-S (iron-sulfur) protein Fd, which is located in the acceptor side of photosystem I (PSI), can be replaced by a functionally equivalent non-Fe-containing Fld in most cyanobacteria and some eukaryotic algae including diatoms (Zurbriggen et al., 2007). The small (6-15 kDa) nonheme protein $\mathrm{Fd}$ accepts electrons from PSI and transfers them to $\mathrm{Fd} \mathrm{NADP}^{+}$reductase (FNR), acting in both cyclic and non-cyclic electron transport systems (LaRoche et al., 1999). By comparison, Fld, a flavoprotein ranging from 16$20 \mathrm{kDa}$ (Zurbriggen et al., 2007), has an oxidation-reduction 


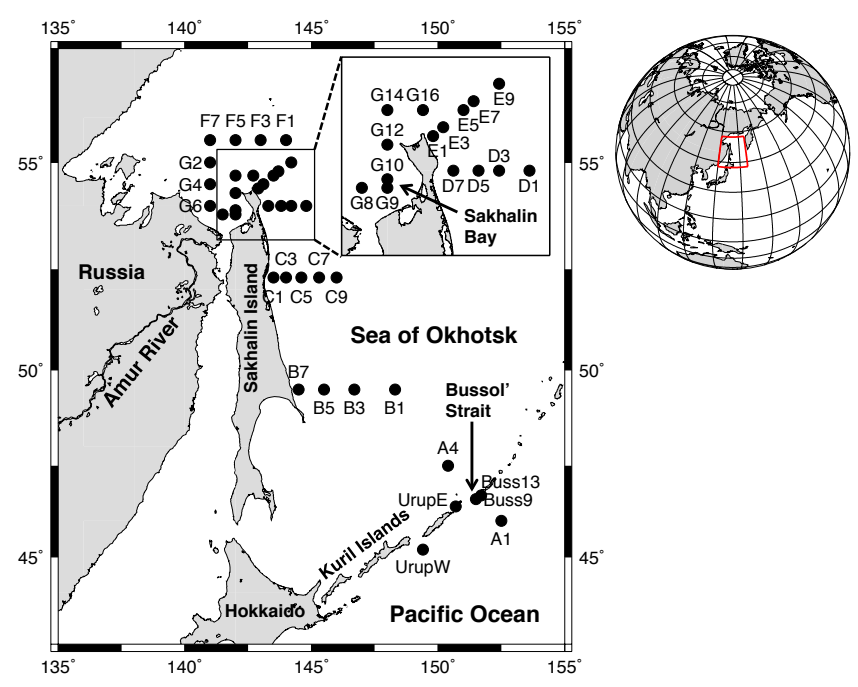

Fig. 1. Maps of the Sea of Okhotsk and its adjacent waters. Closed circles indicate our sampling stations during the R/V Prof. Khromov cruise between 13 August and 14 September 2006.

potential resembling that of $\mathrm{Fd}$ (ca. $-400 \mathrm{mV}$; Medina and Gómez-Moreno, 2004), while the energetic cost of Fld synthesis could be slightly higher than that of Fd due to the larger size. The Fd index or the abundance of Fld have been used as diagnostic markers for cellular Fe status in marine diatoms in the laboratory and field (e.g., LaRoche et al., 1996; Erdner and Anderson, 1999; McKay et al., 1999; Pankowski and McMinn, 2009a; Suzuki et al., 2009; Hattori-Saito et al., 2010). The protein expression assays can obviate the weaknesses of conventional bottle incubation methods (i.e., socalled the bottle effect; Carpenter and Lively, 1980, and trace metal contamination; Fitzwater et al., 1982), because they do not require any bottle incubation. The immunochemical detection of Fd and Fld with the western blot technique used in this study are useful to estimate taxon-specific Fe nutritional status in a semi-quantitative manner. Although $\mathrm{Fd}$ and Fld analyses with high-performance liquid chromatography (HPLC) can yield more quantitative data (Doucette et al., 1996; Erdner and Anderson, 1999), the HPLC technique would require a large quantity of extracted protein and cannot provide taxonomic discrimination. In this study, we revealed using the immunochemical Fd and Fld assays that there was a distinct gradient of $\mathrm{Fe}$ nutritional status in the micro-sized diatoms from near the Amur River mouth to open waters in the Sea of Okhotsk.

\section{Materials and methods}

\subsection{Hydrographic observations}

Our observations were conducted in the Sea of Okhotsk from 13 August to 14 September 2006, on board the Russian R/V Professor Khromov as part of the Amur-Okhotsk project of the Research Institute of Humanity and Nature (RIHN), Japan. The sampling stations were located in the western part of the Sea of Okhotsk, which is influenced by the Amur River, the Bussol' Strait and off the strait in the western subarctic Pacific (Fig. 1). Seawater samples except for the ferredoxin (Fd) and flavodoxin (Fld) assays and $F_{\mathrm{v}} / F_{\mathrm{m}}$ measurements described below were obtained from the surface (2-6 m) using a CTD carousel multi-sampler system (CTD-CMS) with acid-cleaned Teflon-coated Niskin-X bottles. Nutrients (nitrate plus nitrite, phosphate, and silicate) were determined with a segmented continuous flow autoanalyzer (QuAAtro, Bran + Luebbe) following the manufacturer's protocol. The procedure of $\mathrm{Fe}$ analysis is detailed in Nishioka et al. (2011, 2014). In brief, subsampling was done with $0.22 \mu \mathrm{m}$ Durapore filters (Millipak 100, Millipore Corp.) connected to the water sampler Niskin-X spigot, and the filtrate was collected in acid-cleaned LDPE bottles under gravity pressure. The filtrate samples were maintained at $\mathrm{pH} \sim 2$ for more than one month at room temperature, and then the $\mathrm{pH}$ was adjusted to 3.2 immediately before analysis onshore. The dissolved Fe (leachable Fe in $0.22 \mu \mathrm{m}$ filtrate; hereafter D-Fe) was analyzed with a FIA chemiluminescence detection system (Obata et al., 1993). For chlorophyll (Chl) $a$ measurements, seawater samples were filtered onto $25 \mathrm{~mm}$ Whatman GF/F glass-fiber filters under gentle vacuum $(<0.013 \mathrm{MPa})$. After filtration, the filters were soaked in $6 \mathrm{~mL} \mathrm{~N}, N$-dimethylformamide (DMF) in a glass cuvette at $-20^{\circ} \mathrm{C}$ for over a day to extract algal pigments (Suzuki and Ishimaru, 1990). The Chl $a$ concentration was determined using a Turner Designs 10-AU fluorometer following the non-acidification method of Welshmeyer (1994).

\subsection{Light microscopy}

Seawater collected with the Niskin-X bottles was preserved using $20 \%$ formalin buffered with sodium acetate $(0.5 \%$ final concentration; Horner, 2002) before analysis. The samples were concentrated on land using Utermöhl chambers (Hydro-Bios Apparatebau $\mathrm{GmbH}$ ) and analyzed with a Leica DM IL inverted microscope. Identification of diatoms was carried out following Tomas (1997). Micro-sized diatoms were identified with $\geq 20 \mu \mathrm{m}$ in apical, transapical or pervalvar axes. Cell volumes were estimated for each species by applying cellular dimensions to the formulae for solid geometric shapes most closely matching the shapes of the cells (Hillebrand et al., 1999). The carbon biomass of diatoms was calculated with the empirical equations of Menden-Deuer and Lessard (2000). To examine the dissimilarity of the diatom species detected (i.e., species richness) among the stations, a similarity matrix was obtained using the Bray-Curtis index (Bray and Curtis, 1957) and the program EstimateS (ver. 9.1.0; Colwell, 2013). For constructing the matrix, the presence or absence of diatom species in a sample was scored as 1 (present) or 0 (absent). An unweighted pair group clustering method using the arithmetic mean (UPGMA) was 
applied to the similarity matrix to classify the stations into groups.

\subsection{Ferredoxin (Fd) and flavodoxin (Fld) assays}

Seawater was collected from the water intake (ca. $5 \mathrm{~m}$ ) of the research vessel and filtered through a plankton net of $20 \mu \mathrm{m}$ nylon mesh followed by passing through $200 \mu$ m nylon mesh to remove large zooplankton. After the pre-filtration, cells were collected onto $5 \mu \mathrm{m}$ nylon mesh, rinsed from the nylon mesh with the filtered seawater prepared with Whatman GF/F filters, and concentrated into a pellet by centrifugation. The samples obtained were stored in liquid nitrogen or a deep-freezer $\left(-80^{\circ} \mathrm{C}\right)$ until analysis on land. Levels of diatom-specific Fd and Fld in the microplankton sizefraction $(20-200 \mu \mathrm{m})$ were determined following Suzuki et al. (2009) with a few modifications. Single or duplicate samples per sampling station were analyzed and the duplicate data obtained were averaged. In brief, a pellet was sonicated with a Branson SONIFIER model 250 in ice-cold acetone containing $10 \%$ trichloroacetic acid (TCA) and $0.07 \% 2$ mercaptoethanol, and the extracts were stored at $-20^{\circ} \mathrm{C}$ for $1 \mathrm{~h}$. Precipitated protein was centrifuged, rinsed with acetone, suspended in $1 \%$ SDS solution, and heated at $95^{\circ} \mathrm{C}$ for 3 min. Total protein concentration in the solution was determined with BCA assay (Pierce). The protein solution was mixed with an equal volume of $2 \times$ PAGE-reducing sample buffer with SDS-Tris-Gly buffer (Laemmli, 1970). For SDS-PAGE, samples containing $10 \mu \mathrm{g}$ of protein and positive controls of Fd or Fld (see below) were resolved by electrophoresis at $20 \mathrm{~mA}$ for $3-4 \mathrm{~h}$ at room temperature. Gels were transferred to PVDF membranes at $10 \mathrm{~V}$ for $20 \mathrm{~min}$ at room temperature in a Tris buffer containing $20 \%$ methanol. Membranes containing transferred proteins were blocked overnight in phosphate-buffered saline buffer containing Tween 20 (PBST) and 1\% bovine serum albu$\min$. Blots were subsequently incubated for $1 \mathrm{~h}$ with primary antibody diluted $(1: 10000)$ in Can Get Signal Solution 1 (Toyobo Co. Ltd.) for anti-Fd or in PBST for anti-Fld antibodies against diatoms followed by rinsing in the respective buffers $(3 \times 10 \mathrm{~min})$. The anti-Fd antibody was raised against an antigen of the synthetic peptide, N-LVHQEDELY$\mathrm{C}$, corresponding to the $\mathrm{C}$-terminal end of Fd encoded by the pet $F$ gene of diatoms. The anti-Fld antibody derived from diatom protein is detailed in LaRoche et al. (1995). The blots were incubated for $1 \mathrm{~h}$ with donkey anti-rabbit IgGhorseradish peroxidase conjugate diluted in each buffer solution $(1: 25000)$. Immunoreactive proteins were detected by chemiluminescence using the ECL Plus reagent set (GE Healthcare), and the chemiluminescent signal was captured with a cooled CCD camera (Ez-Capture, Atto Co. Ltd.). The bands obtained were quantified with Gel-Pro Analyzer (ver. 4.5) software (Media Cybernetics). The intensity of each band was normalized to that of the positive controls of $\mathrm{Fd}$ or Fld, which were obtained from the synthetic peptide con- nected to a $27 \mathrm{kDa}$ carrier protein (New England Bio Labs) and from an Fe-deficient culture of the centric diatom Thalassiosira nordenskioeldii, respectively. To evaluate the extent of Fe deficiency in micro-sized diatoms, we adopted the $\mathrm{Fd}$ index (i.e. $\mathrm{Fd} /(\mathrm{Fd}+\mathrm{Fld}))$ proposed by Doucette et al. (1996). In Fe-sufficient algae, the Fd index approaches 1 (e.g., Li et al., 2004; Strzepek and Harrison, 2004), indicating that only Fd has accumulated in the cells.

\subsection{HPLC pigment analysis}

For estimating phytoplankton community composition in the micro-sized phytoplankton, pigment analyses were conducted with high-performance liquid chromatography (HPLC). The acetone extracts from the pellets for the $\mathrm{Fd}$ and Fld assays (see Sect. 2.3) were filtered through $0.45 \mu \mathrm{m}$ PTFE filters to remove fine particles. The $250 \mu \mathrm{L}$ filtrate was mixed with $250 \mu \mathrm{L}$ of $28 \mathrm{mM}$ tetrabutylammonium acetate (TBAA) aqueous solution, and $250 \mu \mathrm{L}$ of sample was injected into a Shimadzu CLASS-VP HPLC system equipped with a photodiode array detector (SPD-M10A VP) and a Zorbax Eclipse XDB-C8 column $(3.5 \mu \mathrm{m}$ particle size, $4.6 \times 150 \mathrm{~mm})$. Following Van Heukelem and Thomas (2001), we used a binary solvent system consisting of solvent A (70:30 v/v methanol and $28 \mathrm{mM}$ TBAA at $\mathrm{pH} 6.5$ ) and solvent $\mathrm{B}$ (methanol). The flow rate was held constant at $1.2 \mathrm{~mL} \mathrm{~min}^{-1}$. Pigments were separated with a linear gradient from 5 to $95 \%$ B over the course of $22 \mathrm{~min}$, followed by an isocratic hold at $95 \%$ B for $8 \mathrm{~min}$. The column temperature was kept at $60^{\circ} \mathrm{C}$. Pigment standards were obtained from DHI, Sigma-Aldrich, and Extrasynthese.

\subsection{PAM fluorometry}

The onboard measurements with pulse-amplitudemodulated (PAM) fluorometry were conducted in the vicinity of Sakhalin Island (i.e., Stns B1-G16). An aliquot of the pellets $(20-200 \mu \mathrm{m}$ in size) collected for the Fd and Fld assays (see Sect. 2.3) was suspended in filtered seawater, transferred to acid-cleaned amber-colored high-density polyethylene (HDPE) bottles and placed in an incubator adjusted to the in situ surface water temperature for $30 \mathrm{~min}$ in order to open the reaction centers of photosystem II (PSII) for the micro-sized phytoplankton. The water samples were transferred to a quartz cell under low-light conditions and analyzed in the dark using a Water-PAM fluorometer (Heinz Waltz $\mathrm{GmbH})$ with red LEDs $(650-650 \mathrm{~nm}$ in peak emission) to obtain the maximum photochemical quantum efficiency $\left(F_{\mathrm{V}} / F_{\mathrm{m}}\right)$ of PSII for total micro-sized phytoplankton. The measurements were repeated at least three times and the data obtained were averaged. 
Table 1. Hydrographic properties in surface waters at each sampling station.

\begin{tabular}{|c|c|c|c|c|c|c|c|c|}
\hline Station & $\begin{array}{r}\text { Depth } \\
(\mathrm{m})\end{array}$ & $\begin{array}{r}\text { Temperature } \\
\left({ }^{\circ} \mathrm{C}\right)\end{array}$ & Salinity & $\begin{array}{r}\mathrm{NO}_{3}+\mathrm{NO}_{2} \\
(\mu \mathrm{M})\end{array}$ & $\begin{array}{r}\mathrm{PO}_{4} \\
(\mu \mathrm{M})\end{array}$ & $\begin{array}{r}\mathrm{Si}(\mathrm{OH})_{4} \\
(\mu \mathrm{M})\end{array}$ & $\begin{array}{l}\mathrm{D}-\mathrm{Fe} \\
(\mathrm{nM})\end{array}$ & $\begin{array}{r}\text { Chl } a \\
\left(\mu \mathrm{gL}^{-1}\right)\end{array}$ \\
\hline UrupW & 5 & 5.25 & 33.02 & 17.48 & 1.69 & 28.57 & 0.54 & 2.78 \\
\hline UrupE & 5 & 3.76 & 33.13 & 13.17 & 1.66 & 31.47 & 0.91 & 2.52 \\
\hline Buss9 & 6 & 2.67 & 33.10 & 24.44 & 2.13 & 53.18 & 1.33 & 0.63 \\
\hline Buss 13 & 5 & 2.57 & 33.35 & 27.47 & 2.43 & 56.08 & 0.72 & 0.45 \\
\hline A1 & 5 & 13.87 & 32.76 & 8.77 & 1.12 & 11.30 & 0.43 & 0.43 \\
\hline A4 & 4 & 9.33 & 32.63 & 8.96 & 0.99 & 38.32 & 0.38 & 1.79 \\
\hline B1 & 5 & 13.67 & 32.50 & 0.00 & 0.21 & 0.00 & 0.11 & 0.31 \\
\hline B3 & 5 & 12.82 & 32.26 & 0.05 & 0.16 & 0.00 & 0.25 & 0.63 \\
\hline B5 & 5 & 12.66 & 32.41 & 0.04 & 0.23 & 1.05 & 0.82 & 0.44 \\
\hline B7 & 5 & 10.55 & 32.39 & 0.08 & 0.40 & 0.24 & 3.82 & 0.67 \\
\hline $\mathrm{C} 1$ & 5 & 2.55 & 31.67 & 9.14 & 1.29 & 12.36 & 10.80 & 2.63 \\
\hline C3 & 5 & 10.61 & 31.05 & 0.09 & 0.23 & 0.00 & 3.86 & 0.76 \\
\hline $\mathrm{C} 5$ & 5 & 10.98 & 31.45 & 0.20 & 0.30 & 1.21 & 1.23 & 2.05 \\
\hline $\mathrm{C} 7$ & 5 & 16.06 & 29.70 & 0.22 & 0.27 & 0.59 & 0.77 & 1.65 \\
\hline C9 & 5 & 15.95 & 31.07 & 0.09 & 0.08 & 0.61 & 0.37 & 0.42 \\
\hline D1 & 5 & 12.14 & 30.51 & 1.52 & 0.40 & 3.23 & 0.61 & 5.68 \\
\hline D3 & 5 & 10.47 & 31.01 & 4.01 & 0.56 & 1.45 & 1.21 & 4.99 \\
\hline D5 & 3 & 9.80 & 31.24 & 4.90 & 0.74 & 5.42 & 1.42 & 4.02 \\
\hline D7 & 2 & 13.25 & 28.25 & 0.24 & 0.19 & 5.57 & 1.00 & 3.37 \\
\hline E1 & 6 & 6.24 & 31.19 & 2.77 & 0.76 & 7.64 & 10.08 & 0.93 \\
\hline E3 & 4 & 8.49 & 31.21 & 1.68 & 0.54 & 5.57 & 7.69 & 1.80 \\
\hline E5 & 3 & 12.60 & 28.43 & 0.97 & 0.26 & 5.73 & 5.96 & 1.91 \\
\hline E7 & 5 & 13.67 & 27.44 & 0.33 & 0.15 & 5.23 & 4.52 & 1.81 \\
\hline E9 & 5 & 7.75 & 32.48 & 6.76 & 0.86 & 1.54 & 0.26 & 1.86 \\
\hline $\mathrm{F} 1$ & 2 & 13.09 & 29.72 & 0.00 & 0.15 & 3.41 & 1.16 & 5.58 \\
\hline F3 & 3 & 13.49 & 28.40 & 0.05 & 0.19 & 5.17 & 4.29 & 2.71 \\
\hline F5 & 5 & 12.01 & 30.33 & 0.04 & 0.05 & 5.11 & 2.16 & 2.58 \\
\hline F7 & 5 & 13.91 & 31.40 & 2.13 & 0.03 & 3.79 & 1.70 & 1.52 \\
\hline G2 & 6 & 14.10 & 31.58 & 0.01 & 0.07 & 3.98 & 1.50 & 1.17 \\
\hline G4 & 2 & 11.26 & 31.13 & 0.00 & 0.11 & 0.00 & 2.94 & 3.99 \\
\hline G6 & 5 & 12.97 & 31.16 & 0.09 & 0.24 & 2.47 & 3.64 & 3.10 \\
\hline G8 & 3 & 15.03 & 17.98 & 2.45 & 0.14 & 45.31 & 90.32 & 10.98 \\
\hline G9 & 2 & 15.86 & 16.73 & 0.05 & 0.00 & 26.00 & 56.09 & 15.16 \\
\hline G10 & 5 & 16.18 & 16.74 & 0.18 & 0.03 & 19.65 & 37.56 & 11.45 \\
\hline G12 & 2 & 13.44 & 26.26 & 0.16 & 0.11 & 11.30 & 45.27 & 5.40 \\
\hline G14 & 5 & 13.76 & 31.79 & 0.35 & 0.20 & 6.54 & 4.02 & 1.41 \\
\hline G16 & 2 & 12.59 & 29.00 & 0.10 & 0.15 & 2.82 & 7.55 & 2.18 \\
\hline
\end{tabular}

\section{Results}

\subsection{Hydrography}

In terms of the geographic (Fig. 1) and hydrographic conditions (Table 1, Fig. 2), the study area was divided into two realms: north and east of Sakhalin Island (Stns B1G16) and the vicinity of the Kuril Islands (Stns UrupW-A4). The upper 2-6 $\mathrm{m}$ layer from which we collected samples at each station was within the surface mixed layer. The lowest salinity was observed at Stn G9 with the influence of fresh water reaching to Stns C1-C9 ( $<32$ in salinity), consistent with high discharge of fresh water from the Amur River and distributed along the East Sakhalin coast through the southward-flowing East Sakhalin Current (Ohshima et al., 2002). Higher concentrations $(>30 \mathrm{nM})$ of D-Fe were observed at Stns G8-12 near the Amur River mouth, where Chl $a$ levels were also high $\left(>5 \mu \mathrm{g} \mathrm{L}^{-1}\right)$. Off Sakhalin Island, significant correlations between salinity and D-Fe or silicate were found (Fig. 2a; Spearman's rank correlation coefficient) $(\rho>0.5, p<0.01)$. In addition, a correlation between D-Fe and silicate was also high near Sakhalin Island $(\rho=-0.73, p<0.001)$. These results suggest that both $\mathrm{D}$ $\mathrm{Fe}$ and silicate were mainly derived from the Amur River discharge. Nitrate plus nitrite and phosphate levels were generally low $(<1 \mu \mathrm{M})$, although higher levels $(>2 \mu \mathrm{M})$ of nitrate plus nitrite were sometimes observed on the continental shelf along the east coast of Sakhalin Island. A negative correlation 
Table 2. Dominant micro-sized diatoms off (a) Sakhalin Island and (b) the Kuril Islands in terms of carbon biomass ${ }^{\mathrm{a}}$.

\begin{tabular}{lrlr}
\hline (a) Species & Dominancy $(\%)$ & (b) Species & Dominancy $(\%)$ \\
\hline Ditylum brightwellii & 31.22 & Chaetoceros concavicornis & 71.34 \\
Chaetoceros radicans & 19.02 & Corethron criophilum & 8.95 \\
Ch. debilis & 17.65 & Thalassiosira spp. & 3.80 \\
Coscinodiscus spp. & 10.38 & Pseudo-nitzschia seriata complex & 3.62 \\
Chaetoceros spp. & 8.18 & Chaetoceros spp. & 3.42 \\
Pseudo-nitzschia seriata complex & 5.56 & Neodenticula seminae & 2.77 \\
Thalassiosira spp. & 2.46 & Rhizosolenia setigera & 1.98 \\
Rhizosolenia setigera & 1.62 & Fragilariopsis spp. & 1.88 \\
Skeletonema costatum & 1.31 & Proboscia alata & 0.42 \\
Thalassionema nitzschioides & 0.91 & Cylindrotheca closterium & 0.39 \\
Minidiscus sp. & 0.70 & Navicula spp. & 0.37 \\
Nitzschia spp. & 0.33 & Lioloma spp. & 0.31 \\
Ch. concavicornis & 0.21 & Bacterosira bathyomphala & 0.30 \\
Navicula spp. & 0.13 & Coscinodiscus spp. & 0.30 \\
Fragilariopsis spp. & 0.12 & Guinardia delicatula & 0.09 \\
Corethron criophilum & 0.07 & Others & 0.06 \\
Neodenticula seminae & 0.06 & & \\
Guinardia delicatula & 0.06 & & \\
Cylindrotheca closterium & 0.01 & & \\
\hline
\end{tabular}

${ }^{a}$ The dominancy of each species was estimated against the total carbon biomass of the micro-sized diatoms.

(a)

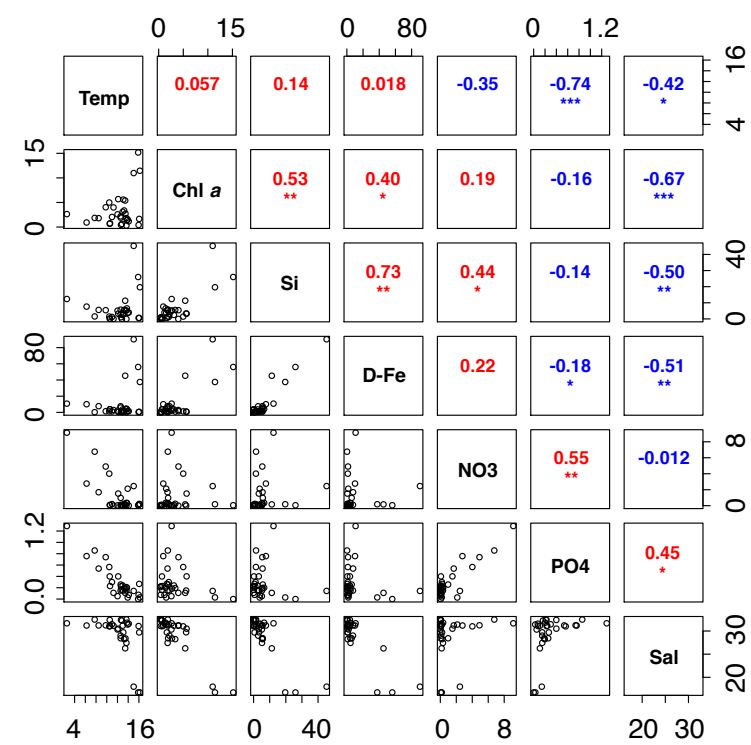

(b)

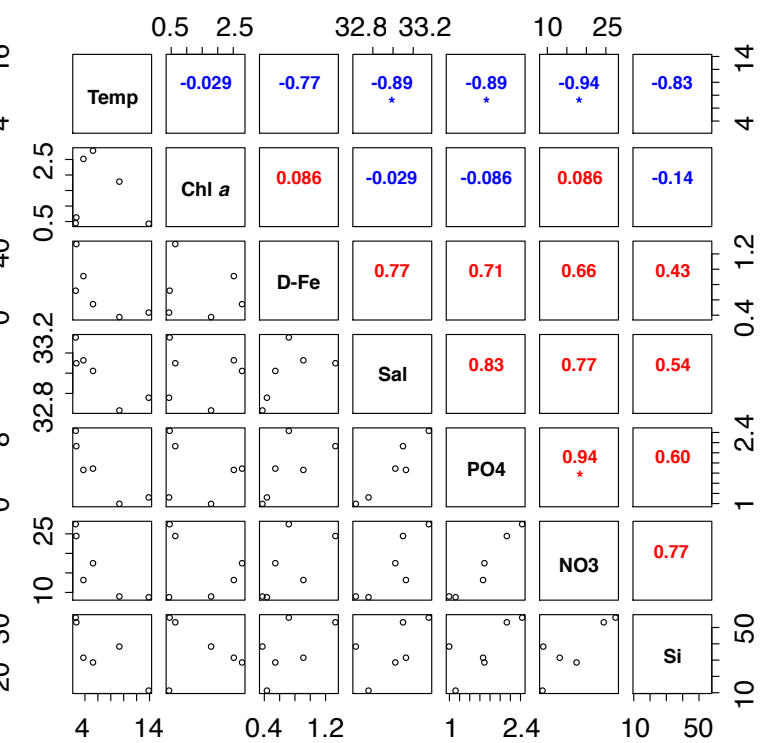

Fig. 2. Multi-panel display of pairwise relationships between the environmental variables, which are listed in Table 1: (a) off Sakhalin Island (Stns B1-G16) and (b) off the Kuril Islands (Stns UrupW-A4) with Spearman's rank correlations $(\rho)$. The Temp, Si, NO 3 , and Sal correspond to temperature, $\mathrm{Si}(\mathrm{OH})_{4}, \mathrm{NO}_{3}+\mathrm{NO}_{2}$, and salinity, respectively. The symbols ***,**, and * indicate the significance levels $p<0.001,<0.01$, and $<0.05$, respectively.

( $\rho=-0.67, p<0.001$ ) between salinity and Chl $a$ biomass was observed off Sakhalin Island.

At Stns UrupW-A4 off the Kuril Islands, salinity, and macronutrient levels were substantially higher than those at the stations off Sakhalin Island (Table 1). The highmacronutrient concentrations were induced coincident with intense tidal-flow-induced vertical mixing (Yagi and Yasuda, 2012). Significant negative correlations between temperature and nitrate plus nitrite or phosphate also existed (Fig. 2b). Both D-Fe and Chl $a$ concentrations were variable among stations $\left(0.38-1.33 \mathrm{nM}\right.$ and $0.43-2.78 \mu \mathrm{g} \mathrm{L}^{-1}$, respectively) 


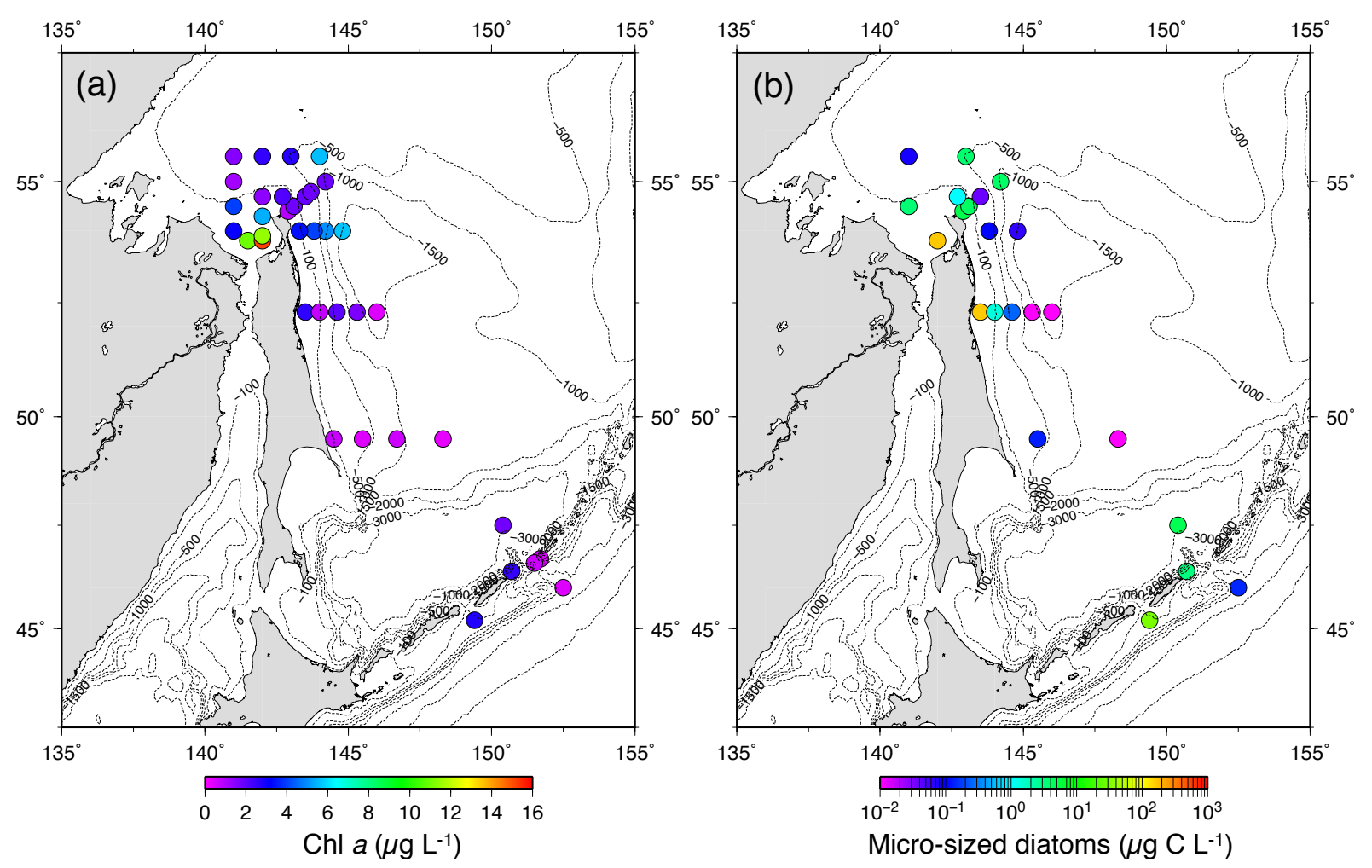

Fig. 3. Plots of (a) chlorophyll (Chl) $a\left(\mu \mathrm{g} \mathrm{L}^{-1}\right)$ concentration and (b) micro-sized diatoms' carbon biomass $\left(\mu \mathrm{g} \mathrm{C} \mathrm{L}^{-1}\right)$ in surface waters at each sampling station.

and they did not show significant relationship with the other environmental parameters off the Kuril Islands.

\subsection{Micro-sized diatoms}

The distribution pattern of the carbon biomass of micro-sized diatoms was generally similar to that of $\mathrm{Chl} a$ biomass in the study area (Fig. 3). The carbon biomass of these diatoms at neritic Stns G9 and C1 was relatively high $\left(>100 \mu \mathrm{g} \mathrm{L} \mathrm{L}^{-1}\right)$, whereas its concentration tended to decrease offshore from the east coast of Sakhalin Island. The dominant microsized diatoms principally consisted of the centrics Ditylum brightwelii, Chaetoceros radicans, Ch. debilis, and Coscinodiscus spp. in the vicinity of Sakhalin Island (Table 2a). By comparison, Ch. concavicornis predominated the microsized diatoms near the Kuril Islands (Table 2b). The compositions of the micro-sized diatoms detected in the vicinity of the Kuril Islands (i.e., at Stns UrupW, UrupE, A1, and A4) were similar to each other (Fig. 4), whereas those off Sakhalin Island were rather spatially variable.

\subsection{Fd index}

Relative intensities of Fd and Fld were variable among stations (Fig. 5). No relationship was found between each intensity and D-Fe or carbon biomass of micro-sized diatoms (Spearman's rank correlation, $p>0.05$ ). Intensities of $\mathrm{Fd}$ plus Fld $(<0.04)$ at Stns F1-G4 and G16 were lower than those at other stations (Fig. 5) and were close to the detection limit (i.e., background levels). Therefore, values of the Fd index at Stns F1-G4 and G16 were not used for further analyses. The cut off value of 0.04 corresponded to $3 \%$ of the maximum intensity (1.33) of Fd plus Fld at Stn B1. The low intensities $(<0.04)$ of Fd plus Fld were probably caused by the high amount of proteins derived from detritus and microsized plankton other than diatoms (e.g., dinoflagellates and planktonic ciliates).

A high-Fd index ( $>0.9$ ) was measured for the micro-sized diatoms sampled at Stns G8 and G10 where D-Fe concentrations were also high (Fig. 6 and Table 1). Both the Fd index and $\mathrm{D}$-Fe tended to be lower offshore from near the mouth of the Amur River. Although no significant relationship was observed between salinity and the Fd index near Sakhalin Island (Fig. 7), a high correlation was found between D-Fe and the Fd index in this area (Fig. $8 \mathrm{a} ; \rho=0.87, p<0.001$ ). In the vicinity of the Kuril Islands, only Fld was detected (Fig. 5), resulting in a Fd index of zero (Fig. 6a).

\subsection{Pigments in micro-sized phytoplankton}

The major chemotaxonomic algal pigments detected were Chl $a$, fucoxanthin (Fucox), and peridinin (Peri). Relative compositions (\%) of these pigments are shown in Fig. 9. As 


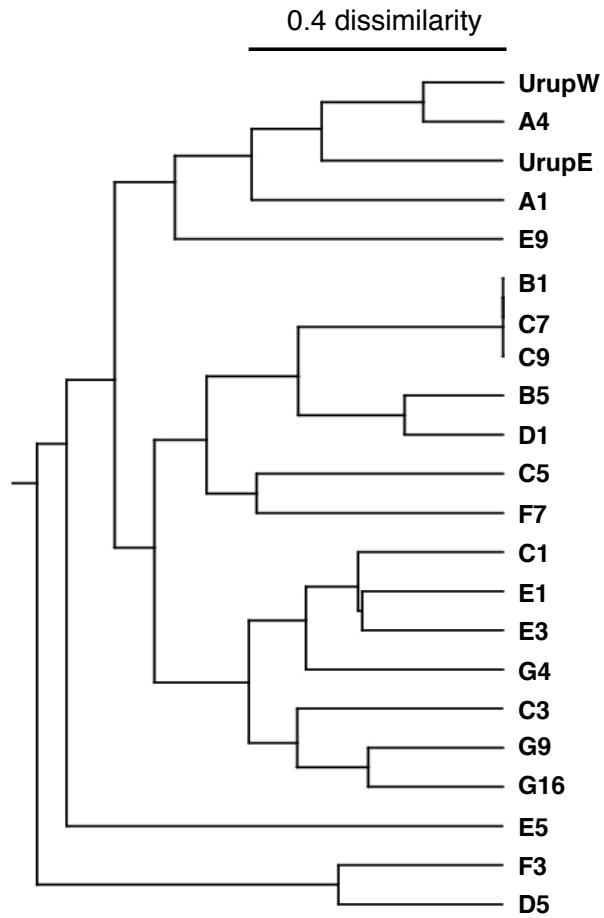

Fig. 4. Cluster dendrogram of the diatom species richness at each sampling station.

pellet size was not constant between samples, absolute pigment levels in the pellets were not estimated. Phaeopigments such as phaeophorbide $a$ were rarely detected, indicating that $10 \%$ TCA in the acetone extracts $(\mathrm{pH} \sim 5)$ had minimal affect on the pigment compositions. As a haptophyte marker, $19^{\prime}$-hexanoyloxyfucoxanthin was occasionally detected, but the pigment was minor. A multiple regression analysis was conducted using Chl $a$, Fucox, and Peri, assuming that Fucox and Peri were derived from diatoms and dinoflagellates, respectively (Vidussi et al., 2001). Although it is known that some dinoflagellates contain Fucox (Zapata et al., 2012), these could not be identified in this study. As a result, we obtained the following regression equation:

$[$ Chl $a]=1.71[$ Fucox $]+0.90[$ Peri $]$

$\left(R^{2}=0.97, F-\right.$ value $\left.=587, p<0.01\right)$,

where [Chl $a$ ], [Fucox], and [Peri] are the concentrations of Chl $a$, Fucox, and Peri in the acetone extracts and those correspond to the fractions of each pigment in Fig. 9. The coefficient (1.71) of Fucox was within the typical ratio between 1.4 and 1.8 for diatoms (Vesk and Jeffrey, 1977), while that of Peri (0.90) was lower than the values (1.5-2.4) reported by Jeffrey et al. (1975) and Vesk and Jeffrey (1977). The regression analysis revealed that diatoms generally became predominant in the micro-sized phytoplankton both near the Kuril Islands and near the coast of Sakhalin Island or the mainland of Russia, whereas Peri-containing dinoflagellates

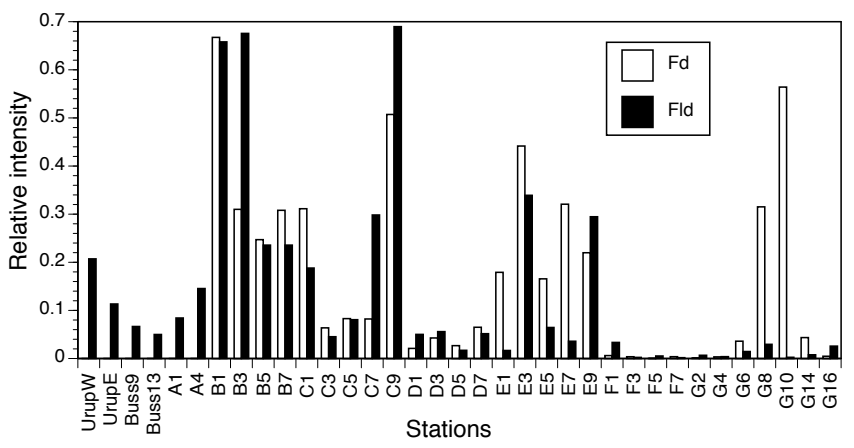

Fig. 5. Relative intensities of ferredoxin (Fd) and flavodoxin (Fld) in micro-sized diatoms in surface waters at each sampling station.

tended to dominate in the more open waters of the Sea of Okhotsk (Fig. 10).

\subsection{PAM fluorometry}

Higher $F_{\mathrm{v}} / F_{\mathrm{m}}$ values for the microphytoplankton were observed in and around Sakhalin Bay (Stns F1-G16 and E13 , respectively; Fig. 11). In particular, $F_{\mathrm{v}} / F_{\mathrm{m}}$ was the highest (0.791) at Stn G8 where D-Fe levels were elevated and macronutrients had not been depleted (Table 1). The maximum theoretical value of $F_{\mathrm{v}} / F_{\mathrm{m}}$ for eukaryotic algae is generally considered to be $0.6-0.8$ as estimated from multiple turnover PAM fluorometry (Büchel and Wilhelm, 1993). Values of $F_{\mathrm{v}} / F_{\mathrm{m}}$ tended to become lower offshore from near the mouth of the Amur River coincident with both declining $\mathrm{D}-\mathrm{Fe}$ and $\mathrm{Fd}$ index. A significant relationship between salinity and $F_{\mathrm{V}} / F_{\mathrm{m}}$ was also observed near the Sakhalin Island (Fig. 7b; $\rho=0.56, p<0.001$ ). Similarly, relationships between D-Fe and $F_{\mathrm{v}} / F_{\mathrm{m}}$ (Fig. $8 \mathrm{~b} ; \rho=0.62, p<0.001$ ) and between $F_{\mathrm{v}} / F_{\mathrm{m}}$ and the Fd index (Fig. 12; Pearson correlation coefficient $r=0.62, p<0.01$ ) were also statistically significant, whereas no relationship was found between nitrate plus nitrite and $F_{\mathrm{v}} / F_{\mathrm{m}}(\rho=0.30, p>0.05)$.

\section{Discussion}

In this study, nutrient limitation is defined as a reduction in the growth rate of phytoplankton due to the low concentration of a nutrient (Liebig's law of the minimum), which might be reflected in $F_{\mathrm{v}} / F_{\mathrm{m}}$ (Boyd et al., 2005). On the other hand, nutrient stress is defined as a physiological adjustment of phytoplankton to lower nutrient availability, which may precede, or occur with or without a reduction in growth rate, and which may be reflected in the Fd index (Boyd et al., 2005). 

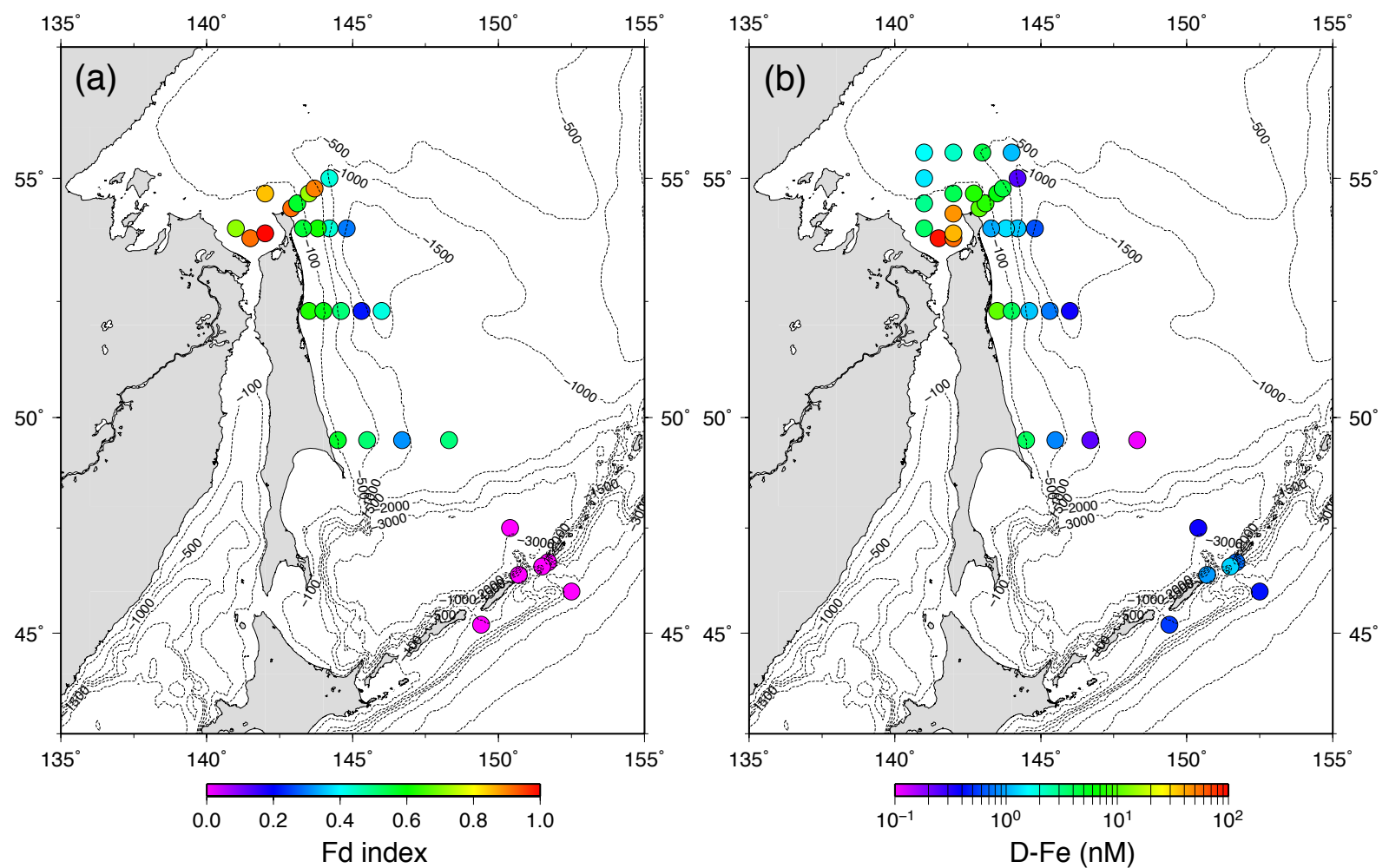

Fig. 6. Plots of (a) the Fd index values for micro-sized diatoms and (b) dissolved iron (D-Fe) concentration (nM) in surface waters at each sampling station.

\subsection{Effect of riverine $\mathrm{Fe}$ input on the physiology of micro-sized diatoms off the Sakhalin Island}

We found that there was a distinct gradient of $\mathrm{Fe}$ nutritional status in the micro-sized diatoms extending from near the mouth of the Amur River to open waters in the Sea of Okhotsk as estimated from the Fd index (Fig. 6a) along with D-Fe data (Fig. 6b). Values of the Fd index significantly correlated with levels of D-Fe (Fig. 8a), indicating that, in general, the Fd index could be used as a diagnostic Fe stress marker for the micro-sized diatoms in this area. However, it should be noted that, in principle, values of the Fd index would be varied with intracellular Fe levels rather than D-Fe concentrations in seawater. Additionally, the Fd index values can also be changed among species in the micro-sized diatoms. Therefore, there could be various Fd index values at a $\mathrm{D}-\mathrm{Fe}$ concentration.

At Stns G8 and G10 near the Amur River, values of the Fd index were $>0.9$, consistent with growth of the micro-sized diatoms under Fe-replete conditions. Nishioka et al. (2014) noted that influence of the Amur River reached to Stns C1C9 (also see Table $1,<32$ in salinity) during the survey. The values of the Fd index at these stations became lower (0.22-0.62), indicating that the $\mathrm{Fe}$ nutritional status of the micro-sized diatoms declined. According to Yoshimura et al. (2010) who conducted Fe-enriched bottle incubation ex- periments in the Sea of Okhotsk during the study, addition of $10 \mathrm{nM}$ inorganic Fe did not stimulate the growth of the large-sized phytoplankton $(>10 \mu \mathrm{m})$ near Stns G9, E2, C3, and C9 (which correspond to Stns 1, 2, 3, and 4 in Yoshimura et al. (2010), respectively). Although the Fd index data were unavailable from Stns G9 and E2, the Fd index measured at nearby locations (i.e., Stn G10 and E1, respectively) was high $(>0.9)$; however, the $\mathrm{Fd}$ index values at Stns C3 and C9 were lower (0.58 and 0.42, respectively). The lower Fd index values observed at Stns C3 and C9 might reflect an early response prior to Fe limitation in the micro-sized diatoms. McKay et al. (1997) and Davey and Geider (2001) demonstrated that Fld accumulation in diatoms occurred in an early stage of Fe-deficient conditions when the growth rates of the diatoms were almost the same as those in Fe-replete conditions. At nearshore Stns C1 and E3 where both D-Fe and $F_{\mathrm{v}} / F_{\mathrm{m}}$ were high $(>7 \mathrm{nM}$ and $>0.6$, respectively) and micro-sized diatoms were abundant $\left(>4 \mu \mathrm{g} \mathrm{CL}{ }^{-1}\right)$, the values of the Fd index were also slightly low (0.62 and 0.57 , respectively). At these stations, the compositions of the micro-sized diatom species observed were similar to each other (Fig. 4). In particular, Chaetoceros radicans and Dithylum brightwellii were predominant at Stns C1 and E3, respectively. These same diatom taxa were observed at other stations where a high-Fd index was reported, suggesting that the lower index value cannot be readily attributed 
(a)

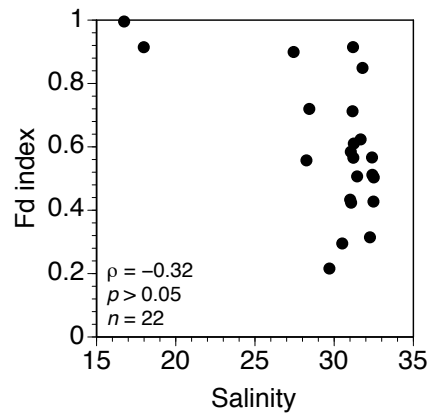

(b)

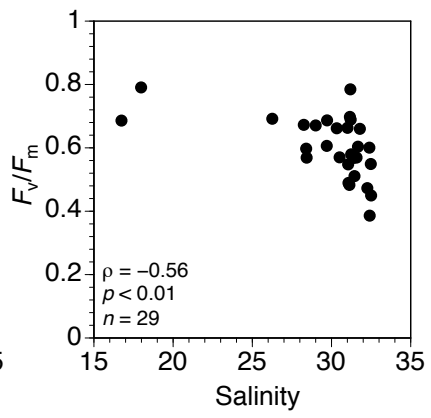

Fig. 7. Relationships between salinity and (a) the Fd index values for micro-sized diatoms or (b) $F_{\mathrm{V}} / F_{\mathrm{m}}$ for total micro-sized phytoplankton in surface waters off Sakhalin Island.
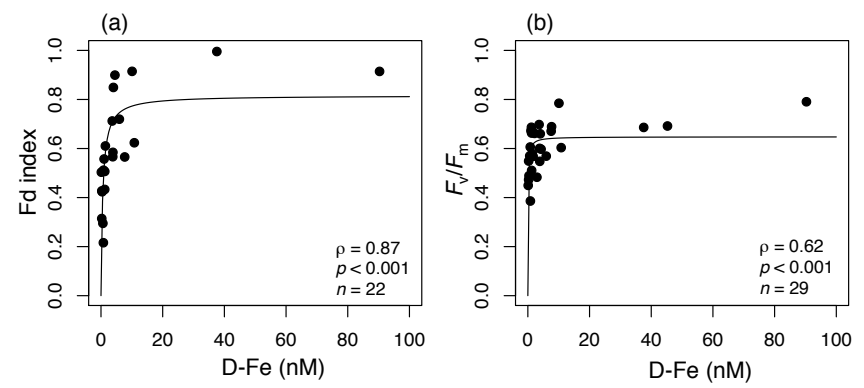

Fig. 8. Relationships between dissolved iron (D-Fe) concentrations $(\mathrm{nM})$ and (a) the Fd index values for micro-sized diatoms or (b) $F_{\mathrm{V}} / F_{\mathrm{m}}$ values for total micro-sized phytoplankton in surface waters off Sakhalin Island. The data obtained were fitted with the Michaelis-Menten equation (see the text).

to methodological considerations such as constitutive expression of Fld under Fe-replete conditions (McKay et al., 2000; Pankowski and McMinn, 2009a, b).

Although the Fd index was highly correlated with D-Fe, the relationship between the salinity and the Fd index was insignificant (Fig. 7a). This was probably related to the fact that the correlation coefficient between salinity and D-Fe was rather low ( $\rho=-0.51, p<0.01$; Fig. $2 \mathrm{a})$, representing the presence of an $\mathrm{Fe}$ sink (i.e., utilization by microorganisms such as phytoplankton and scavenging; Boyd and Ellwood, 2010) along with $\mathrm{Fe}$ sources other than the Amur River discharge. Okunishi et al. (2007) and Misumi et al. (2011) pointed out that atmospheric $\mathrm{Fe}$ deposition and $\mathrm{Fe}$ flux from sediment play important roles in maintaining bioavailable $\mathrm{Fe}$ in surface waters of the Sea of Okhotsk. On the other hand, a correlation between the $F_{\mathrm{v}} / F_{\mathrm{m}}$ values and salinity was observed (Fig. 7b). It is well known that $F_{\mathrm{v}} / F_{\mathrm{m}}$ values can vary with the availability of nitrogen, phosphorous or $\mathrm{Fe}$ (Shelly et al., 2011). Lippemeier et al. (1999) also noted that changes in $F_{\mathrm{v}} / F_{\mathrm{m}}$ could be observed in response to silica limitation and its re-supply to diatoms. Parkhill et al. (2001) proposed that $F_{\mathrm{v}} / F_{\mathrm{m}}$ should be used as a diagnostic indicator for nutrient-

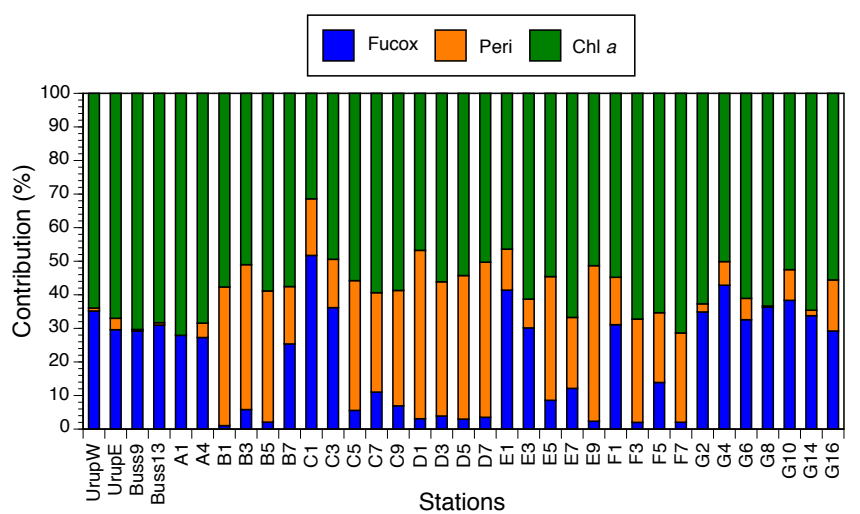

Fig. 9. Relative levels (\%) of fucoxanthin (Fucox), peridinin (Peri), and Chl $a$ to the sum of these pigments in the pellets collected for the Fd and Fld assays at each sampling station.

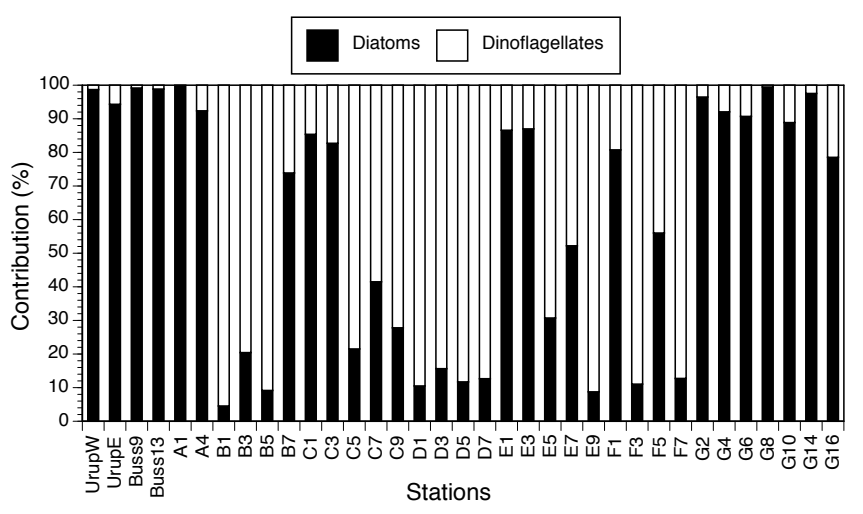

Fig. 10. Relative contributions (\%) of diatoms and peridinincontaining dinoflagellates to the total micro-sized phytoplankton in terms of Chl $a$ biomass.

starved unbalanced growth conditions, because $F_{\mathrm{v}} / F_{\mathrm{m}}$ was not a good measure of nutrient limitation in a neritic diatom under balanced growth conditions and showed a constant high value (ca. 0.65) independent of nutrient-limited growth rate under different irradiance levels. Diurnal variations of $F_{\mathrm{v}} / F_{\mathrm{m}}$ have also been reported previously (e.g., Suzuki et al., 2002; Behrenfeld and Milligan, 2013). Note that the $F_{\mathrm{v}} / F_{\mathrm{m}}$ values obtained in this study were derived not only from the diatoms, but also from the dinoflagellates (Fig. 10). Nonetheless, in this study, the $F_{\mathrm{v}} / F_{\mathrm{m}}$ values significantly correlated with D-Fe concentrations (Fig. 8b), but not with levels of nitrate plus nitrite, suggesting that D-Fe was a major determining factor for $F_{\mathrm{v}} / F_{\mathrm{m}}$ values. A distinct gradient in $F_{\mathrm{v}} / F_{\mathrm{m}}$ values was also observed from near the Amur River mouth to the neritic region at Stns C1 and $\mathrm{C} 3$, where diatoms were predominant in the micro-sized phytoplankton (>80\%; Fig. 10). These results were consistent with the Fd index data. There was also a significant correlation between the $F_{\mathrm{v}} / F_{\mathrm{m}}$ values and the Fd index (Fig. 11), indicating that the photosynthetic physiological conditions 


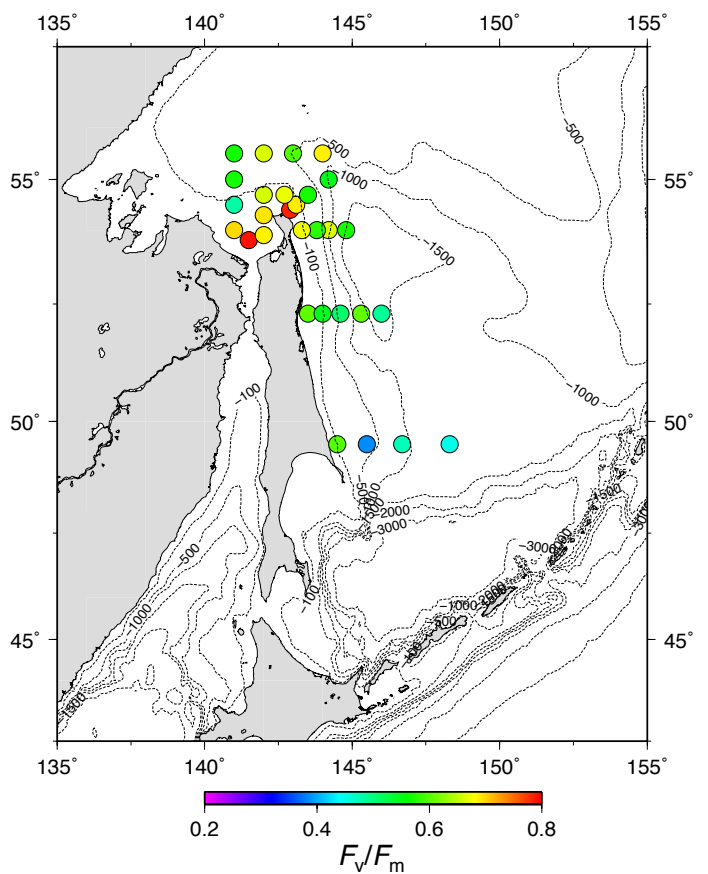

Fig. 11. Plots of $F_{\mathrm{V}} / F_{\mathrm{m}}$ values for total micro-sized phytoplankton in surface waters at each sampling station.

between the diatoms and other micro-sized phytoplankton (i.e., mainly dinoflagellates) were comparable.

If we fit the relationships between $\mathrm{D}-\mathrm{Fe}$ and the $\mathrm{Fd}$ index or $F_{\mathrm{v}} / F_{\mathrm{m}}$ with the Michaelis-Menten equation, the maximum values for the Fd index and $F_{\mathrm{v}} / F_{\mathrm{m}}$ were estimated as $0.82 \pm 0.06$ and $0.65 \pm 0.02$ (mean \pm standard error), respectively (fitting curves in Fig. 8). The lower maximum Fd index value, compared to the theoretical maximum $(=1)$, was mainly caused by the data from Stns C1 and E3 mentioned above. The maximum value $(0.65 \pm 0.02)$ of $F_{\mathrm{v}} / F_{\mathrm{m}}$ was within the theoretical value between $0.6-0.8$ for eukaryotic algae as estimated with multiple turnover PAM fluorometry (Büchel and Wilhelm, 1993). The half saturation constants between D-Fe and the Fd index or $F_{\mathrm{v}} / F_{\mathrm{m}}$ were calculated as $0.56 \pm 0.20 \mathrm{nM}$ and $0.080 \pm 0.028 \mathrm{nM}$ (mean \pm standard error), respectively. Unfortunately, no such field data for direct comparison were available from previous studies. The higher half saturation constant between D-Fe and the Fd index than that between D-Fe and $F_{\mathrm{v}} / F_{\mathrm{m}}$ seems to be reasonable, because Fld accumulation could precede the declines in $F_{\mathrm{v}} / F_{\mathrm{m}}$ or growth rate (McKay et al., 1997; Davey and Geider, 2001). According to Timmermans et al. (2004), the half-saturation constants between $\mathrm{D}-\mathrm{Fe}$ and net growth rate in four large diatoms from the Southern Ocean were between 0.19-1.14 nM, and close to the ambient D-Fe concentrations of $0.2 \mathrm{nM}$. In this study, the half saturation constant $(0.080 \pm 0.028 \mathrm{nM})$ between D-Fe and $F_{\mathrm{v}} / F_{\mathrm{m}}$ might be slightly lower than expected from the ambient D-Fe levels $(>0.2 \mathrm{nM}$ in general; Table 1). It is known that dinoflagellates can migrate ver-

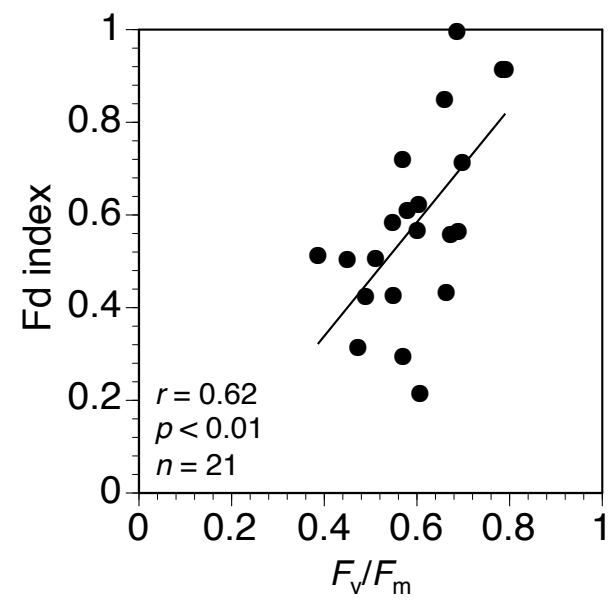

Fig. 12. A relationship between $F_{\mathrm{V}} / F_{\mathrm{m}}$ values for total micro-sized phytoplankton and the Fd index values for micro-sized diatoms in surface waters off Sakhalin Island. A linear regression line is plotted with the data.

tically to assimilate nutrients in subsurface waters (Eppley et al., 1968). Their vertical migration capability could account for the high- $F_{\mathrm{v}} / F_{\mathrm{m}}$ values even under low-Fe conditions at the surface. As mentioned above, the nutrientbalanced growth conditions (Parkhill et al., 2001) might also contribute to this issue. During events of high input of D$\mathrm{Fe}$, which can sometimes be expected in coastal waters, diatoms are capable of luxury accumulation of $\mathrm{Fe}$ within their cells, to be used later under Fe-deficient conditions (Sunda and Huntsman, 1995; Iwade et al., 2006; Marchetti et al., 2009). Therefore, for diatoms, luxury Fe uptake and intracellular Fe storage could play an important role in maintaining the high- $F_{\mathrm{v}} / F_{\mathrm{m}}$ values under low-Fe conditions.

\subsection{Fe deficiency in micro-sized diatoms off the Kuril Islands}

Only Fld was detected in the vicinity of the Kuril Islands (Fig. 5), resulting in a Fd index of zero (Fig. 6a), despite ambient D-Fe levels $>0.4 \mathrm{nM}$ (Table 1). The results suggest that the micro-sized diatoms, which mainly consisted of Chaetoceros concavicornis and the species was minor off the Sakhalin Island (Table 2), were growing under Fe-deficient conditions. Otherwise, the constitutive production of Fld in the diatoms could occur even under Fe-replete conditions (McKay et al., 2000; Pankowski and McMinn, 2009a, b), whereas that has never been reported from Chaetoceros spp. The former is supported by the results of Fe-enriched bottle incubation experiments conducted in the Bussol' Strait by Yoshimura et al. (2010) and Sugie et al. (2013). According to Yoshimura et al. (2010), net specific growth rate of large-sized $(>10 \mu \mathrm{m})$ phytoplankton, which mainly consisted of the genus Chaetoceros, was significantly enhanced by a $10 \mathrm{nM}$ inorganic Fe addition, as compared with the 
unamended control. More recently, Sugie et al. (2013) also confirmed that additions of inorganic Fe (final concentration of $5 \mathrm{nM}$ ) or particulate Fe, which was collected from the nepheloid layer in the coastal region of the Sea of Okhotsk, stimulated the growth of diatoms in the Bussol' Strait during summer 2007, although the cell size of the diatoms was not indicated. As a plausible mechanism promoting Fe deficient conditions in the micro-sized diatoms near the Bussol' Strait, Fe and light co-limitations (Sunda and Huntsman, 1997) were considered. The strong vertical mixing in the Bussol' Strait (Yagi and Yasuda, 2012) could facilitate transport of the diatoms from the surface to deeper layer and vice versa. Indeed, vertical profiles of $\mathrm{Chl} a$ biomass in the Bussol' Strait were entirely uniform from the surface to $200 \mathrm{~m}$ (data not shown) as were those of temperature and salinity (see Yoshimura et al., 2010). Additionally, daily surface PAR was relatively low $\left(21 \pm 6 \mathrm{~mol}\right.$ photons $\left.\mathrm{m}^{-2} \mathrm{~d}^{-1}\right)$ in this region due to heavy cloud cover, compared to that measured at other stations during the cruise (Isada et al., 2013). These physical conditions could cause light limitation of the growth of the micro-sized diatoms. According to Sunda and Huntsman (1997) and Strzepek and Harrison (2004), higher amounts of $\mathrm{Fe}$ are required for diatoms growing under lowlight conditions, because more $\mathrm{Fe}$ is required for the synthesis of the photosynthetic apparatus including pigments to capture more light energy. Therefore, the micro-sized diatoms off the Kuril Islands possibly encountered Fe and light co-limitations.

Interestingly, the values of the Fd index at Stns A1 and A4, which were slightly apart from the Bussol' Strait, showed the same results as those at other stations near the strait (i.e., Fd index $=0$ ). These data suggest efficient water transport from the Sea of Okhotsk to the North Pacific via the Kuril Straits (Ohshima et al., 2002; Kida and Qiu, 2013). Indeed, the compositions of the micro-sized diatom species detected between Stns A1 and A4 were similar to each other (Fig. 4). Jing et al. (2009) also demonstrated similar phylotype compositions of picoplankton-sized cyanobacteria Synechococcus spp. between Stns A1 and A6, which was located between Stn A4 and $\mathrm{B} 1$ during the cruise.

\section{Conclusions}

The coastal area is a key environment in the global Fe cycle, where the brackish water environment changes the physicochemical speciation (i.e., mobility) of riverine $\mathrm{Fe}$ via aggregation, sedimentation, and redox processes (Boyd and Ellwood, 2010; Breitbarth et al., 2010). Therefore, the coastal waters become a highly dynamic transition zone, resulting in diverse spatiotemporal chemical and biological changes. In this study, we revealed that there was a distinct gradient in the Fe nutritional status of the micro-sized diatoms from near the mouth of the Amur River to the oceanic region of the Sea of Okhotsk using the Fd index. In addition, uniformly low-
Fd index values suggested widespread Fe deficiency of the micro-sized diatoms near the Kuril Straits. The differential expressions of Fd and Fld in the micro-sized diatoms helped us to understand how these microorganisms responded to $\mathrm{Fe}$ availability in the Sea of Okhotsk without reliance on incubation approaches which are often accompanied by bottle effects (Carpenter and Lively, 1980) and trace metal contamination (Fitzwater et al., 1982). Recently, Whitney et al. (2011) succeeded in examining the expression of selected genes such as Fd and Fld genes in two diatom Thalassiosira strains with real-time quantitative reverse transcription PCR (qRT-PCR). Although the micro-sized diatoms play important roles in the marine ecosystems and biogeochemical processes, such molecular-based physiological knowledge has still been very scarce, especially applied to the field. We expect that recent rapid advances in metagenomics, metatranscriptomics, and metaproteomics using next-generation sequencing technologies and high-precision mass spectrometry with advanced bioinformatics (Rusch et al., 2010; Marchetti et al., 2012; Desai et al., 2012; DeLong, 2013) will lead to further understanding of how phytoplankton including the micro-sized diatom species have adapted to a wide variety of in situ Fe conditions, and the implications of their adaptations to algal productivity and biodiversity.

Acknowledgements. We wish to thank the captain, officers, crew and scientists of the R/V Professor Khromov for their helpful assistance during the cruise. In particular, the chief scientist Prof. Takeshi Nakatsuka must be acknowledged. We also thank Kyoko Kawanobe for light microscopy. Two anonymous referees are also acknowledged for their constructive comments and suggestions on the manuscript. This study was supported by the project "Human Activities in Northeastern Asia and Their Impact on the Biological Productivity in the North Pacific Ocean" of the Research Institute of Humanity and Nature (RIHN), JSPS Grant-in-Aid for Scientific Research (no. 19510001, no. 22221001, no. 22310002, and no. 24121004) and the CREST project of the Japan Science and Technology Agency.

Edited by:

\section{References}

Aguilar-Islas, A. M., Hurst, M. P., Buck, K. N., Sohst, B., Smith, G. J., Lohan, M. C., and Bruland, K. W.: Micro- and macronutrients in the southeastern Bering Sea: Insight into iron-replete and irondepleted regimes, Prog. Oceanogr., 73, 99-126, 2007.

Andreev, A. G. and Pavlova, G. Y.: Okhotsk Sea, in: Carbon and Nutrient Fluxes in Continental Margins: A Global Synthesis, Global Change - The IGBP Series, Liu, K.-K., Atkinson, L., Quiñones, R., Talaue-McManus, L. (Eds.), Springer, Berlin, 394-405, 2009.

Behrenfeld, M. J. and Milligan, A.: Photophysiological expressions of iron stress in phytoplankton. Annu. Rev. Mar. Sci., 5, 217-246, 2013.

Boyd, P. W., Strzepek, R., Takeda, S., Jackson, G., Wong, C. S., McKay, R. M., Law, C., Kiyosawa, H., Saito, H., Sherry, N., 
Johnson, K., Gower, J., and Ramiah, N., The evolution and termination of an iron-induced mesoscale bottom in the northeast subarctic Pacific, Limnol. Oceanogr., 50, 1872-1886, 2005.

Boyd, P. W., Jikells, T., Law, C. S., Blain, S., Boyle, E. A., Buesseler, K. O., Coale, K. H., Cullen, J. J., de Baar, H. J. W., Follows, M., Harvey, M., Lancelot, C., Lavasseur, M., Owens, N. P. J., Pollard, R., Rivkin, R. B., Sarmiento, J., Schoemann, V., Smetacek, V., Takeda, S., Tsuda, A., Turner, S., and Watson, A. J.: Mesoscale iron enrichment experiments 1993-2005: Synthesis and future directions, Science, 315, 612-617, 2007.

Boyd, P. W. and Ellwood, M. J.: The biogeochemical cycle of iron in the ocean, Nature Geosci., 3, 675-682, 2010.

Boyle, E. A., Edmond, J. M., and Sholkovitz, E. R.: The mechanism of iron removal in estuaries, Geochim. Cosmochim. Acta, 41, 1313-1324, 1977.

Bray, J. R. and Curtis, J. T.: An ordination of the upland forest communities of southern Wisconsin. Ecol. Monogra. 27, 325-349, 1957.

Breitbarth, E., Achterberg, E. P., Ardelan, M. V., Baker, A. R., Bucciarelli, E., Chever, F., Croot, P. L., Duggen, S., Gledhill, M., Hassellöv, M., Hassler, C., Hoffmann, L. J., Hunter, K. A., Hutchins, D. A., Ingri, J., Jickells, T., Lohan, M. C., Nielsdóttir, M. C., Sarthou, G., Schoemann, V., Trapp, J. M., Turner, D. R., and Ye, Y.: Iron biogeochemistry across marine systems progress from the past decade, Biogeosciences, 7, 1075-1097, doi:10.5194/bg-7-1075-2010, 2010.

Bruland, K. W., Rue, E. L., and Smith, G. J.: Iron and macronutrients in California coastal upwelling regimes: Implications for diatom blooms, 46, 1661-1674, 2001.

Büchel, C. and Wilhelm, C.: In vivo analysis of slow chlorophyll fluorescence induction kinetics in algae: progress, problems and perspectives, Phytochem. Phytobiol., 58, 137-148, 1993.

Buck, K.N., Lohan, M. C., Berger, C. J. M., and Bruland, K. W.: Dissolved iron speciation in two distinct river plumes and an estuary: Implications for riverine iron supply, Limnol. Oceanogr., 52, 843-855, 2007.

Carpenter, E. J. and Lively, J. S.: Review of estimates of algal growth using ${ }^{14} \mathrm{C}$ tracer technique, in: Primary Productivity in the Sea, edited by: Falkowski, P. G., Plenum Press, New York, 161-178, 1980.

Chase, Z., Strutton, P. G., and Hales, B.: Iron links river runoff and shelf width to phytoplankton biomass along the US West Coast, Geophys. Res. Lett., 34, L04607, doi:10.1029/2006GL028069, 2007.

Colwell, R. K.: Estimate S: Statistical estimation of species richness and shared species from samples. Version 9 and earlier. User's Guide and application, http://viceroy.eeb.uconn.edu/estimates/ index.html, 2013.

de Baar, H. J. W., Boyd, P. W., Coale, K. H., Landry, M. R., Tsuda, A., Assmy, P., Bakker, D. C. E., Boze, Y., Barber, R. T., Brzezinski, M. A., Buesseler, K. O., Boyé, M., Croot, P., Gervais, F., Gorbunov, M. Y., Harrison, P. J., Hiscock, W. T., Laan, P., Lancelot, C., Law, C. S., Levasseur, M., Marchetti, A., Millero, F. J., Nishioka, J., Nojiri, Y., van Oijen, T., Riebsell, U., Rijkensberg, M.J.A., Saito, H., Takeda, S., Timmermans, R., Veldhuis, M. J. W., Maite, A.M., and Wong, C. S.: Synthesis of iron fertilization experiments: from the iron age in the age of enlightenment. J. Geophys. Res., 110, C09S16, doi:10.1029/2004JC002601, 2005.
DeLong, E. F.: Microbial Metagenomics, Metatranscriptomics, and Metaproteomics, Methods in Enzymology, 531, Amsterdam, Academic Press, 2013.

Desai, D. K., Desai, F., and LaRoche, J.: Factors influencing the diversity of iron uptake systems in aquatic microorganisms, Front. Microbiol., 3, 1-20, 2012.

Devey, M. and Geider, R. J.: Impact of iron limitation on the photosynthetic apparatus of the diatom Chaetoceros muelleri (Bacillariophyceae), J. Phycol., 37, 987-1000, 2001.

Doucette, G. J., Erdner, D. L., Peleato, M. L., Hartman, J. J., and Anderson, D. M.: Quantitative analysis of iron-stress related proteins in Thalassiosira weissflogii: measurement of flavodoxin and ferredoxin using HPLC, Mar. Ecol. Prog. Ser., 130, 269-276, 1996.

Eppley, R. W., Holm-Hansen, O., and Strickland, J. D. H.: Some observations on vertical migration of dinoflagellates, J. Phycol., 4, 333-340, 1968.

Erdner, D. L. and Anderson, D. M.: Ferredoxin and flavodoxin as biochemical indicators of iron limitation during open-ocean iron enrichment. Limnol. Oceanogr., 44, 1609-1615, 1999.

Fitzwater, S. E., Knauer, G. A., Martin, J. H.: Metal contamination and its effect on primary production measurements, Limnol. Oceanogr., 27, 544-551, 1982.

Gerringa, L. J. A., Alderkamp, A.-C., Laan, P., Thuróczy, C.-E., De Baar, H. J. W., Mills, M. M., van Dijken, G. L., van Haren, H., Arrigo, K. R.: Iron from melting glaciers fuels the phytoplankton blooms in Amundsen Sea (Southern Ocean): Iron biogeochemistry, Deep-Sea Res. Pt. II, 71-76, 16-31, 2012.

Hattori-Saito, A., Nishioka, J., Ono, T., McKay, R. M. L., and Suzuki, K.: Iron deficiency in micro-sized diatoms in the Oyashio region of the western subarctic Pacific during spring, J. Oceanogr., 66, 105-115, 2010.

Hillebrand, H., Dürselen, C.-D., Kirschtel, D., Pollingher, U., Zohry, T.: Biovolume calculation for pelagic and benthic microalgae, J. Phycol., 35, 403-424, 1999.

Horner, R. A.: A Taxonomic Guide to Some Common Marine Phytoplankton, Biopress Ltd., Bristol, UK, 2002.

Hutchins, D. A., Hare, C. E., Weaver, R. S., Zhang, Y., Firme, F., DiTullio, G. R., Alm, M. B., Riseman, S. F., Maucher, J. M., Geesey, M. E., Trick, C. G., Smith, G. J., Rue, E. L., Conn, J., and Bruland, K. W.: Phytoplankton iron limitation in the Humboldt Current and Peru Upwelling, Limnol. Oceanogr., 47, 997-1011, 2002.

Isada, T., Iida, T., Liu, H., Saitoh, S.-I., Nishioka, J., Nakatsuka, T., and Suzuki, K.: Influence of Amur River discharge on phytoplankton photophysiology in the Sea of Okhotsk during late summer, J. Geophys. Res., 118, 1995-2013, 2013.

Iwade, S., Kuma, K., Isoda, Y., Yoshida, M., Kudo, I., Nishioka, J., and Suzuki, K.: Effect of high iron concentration on iron uptake and growth of a coastal diatom Chaetoceros sociale. Aquat. Microb. Ecol., 43, 177-191, 2006.

Jeffrey, S. W., Siellicki, M., and Haxo, F. T.: Chloroplast pigment patterns in dinoflagellates, J. Phycol., 11, 374-384, 1975.

Jing, H., Liu, H., and Suzuki, K.: Phylogenetic diversity of marine Synechococcus spp. in the Sea of Okhotsk, Aquat. Microb. Ecol., 56, 55-63, 2009.

Johnson, K. S., Gordon, R. M., and Coale, K. H.: What controls dissolved iron concentrations in the world ocean? Mar. Chem., 57, 137-161, 1997. 
Kida, S. and Qiu, B.: An exchange flow between the Okhotsk Sea and the North Pacific driven by the East Kamchatka Current, J. Geophys. Res., 118, 6747-6758, 2013.

Kimura, N. and Wakatsuchi, M.: Relationship between sea-ice motion and geostrophic wind in the Northern Hemisphere, Geophs. Res. Lett., 27, 3735-3738, 2000.

LaRoche, J. Murray, H., Orellana, M., and Newton, J.: Flavodoxin expression as an indicator of iron limitation in marine diatoms, J. Phycol., 31, 520-530, 1995.

LaRoche, J., Boyd, P. W., McKay, R. M. L., and Geider, R. J.: Flavodoxin as an in situ marker for iron stress in phytoplankton, Nature, 382, 802-805, 1996.

LaRoche, J., McKay, R. M. L., and Boyd, P.: Immunological and molecular probes to detect phytoplankton responses to environmental stress in nature, Hydrobiologia, 401, 177-198, 1999.

Laemmli, U. K.: Cleavage of structural proteins during the assembly of the head of bacteriophase T4, Nature, 227, 680-685, 1970.

Li, X., Yakunin, A. F., and McKay, R. M. L.: The Fe responsive accumulation of redox proteins ferredoxin and flavodoxin from a marine cryptomonad, Eur. J. Phycol., 39, 73-82, 2004.

Lippermier, S., Hartig, P., and Colijin, F.: Direct impact of silicate on the photosynthetic performance of the diatom Thalassiosira weissflogii assessed by on- and off-line PAM fluorescence measurements, J. Plankton Res., 21, 269-283, 1999.

Marchetti, A., Parker, M. S., Moccia, L. P., Lin, E. O., Arrieta, A. L., Ribalet, F. Murphy, M. E. P., Maldonado, M. T., and Armbrust, E. V.: Ferritin is used for iron storage in bloom-forming marine pennate diatoms. Nature, 457, 467-470, 2009.

Marchetti, A., Schruth, D. M., Durkin, C. A., Parker, M. S., Kodner, R. B., Berthiaume, C. T., Morales, R., Allen, A. E., and Armbrust, E. V.: Comparative metatranscriptomics identifies molecular bases for the physiological responses of phytoplankton to varying iron availability, Proc. Nat. Acad. Sci. USA, 109, E317E325, 2012.

Martin, S., Drucker, R., and Yamashita, K.: The production of ice and dense shelf water in the Okhotsk Sea polynyas, J. Geophys. Res., 103, 27771-27782, 1998.

McKay, R. M. L., Geider, R. J., and LaRoche, J.: Physiological and biochemical response of the photosynthetic apparatus of two marine diatoms to Fe stress, Plant Physiol., 114, 615-622, 1997.

McKay, R. M. L., LaRoche, J., Yakunin, A. F., Durnfor, D. G., and Geider, R. J.: Accumulation of ferredoxin and flavodoxin in a marine diatom in response to Fe. J. Phycol., 35, 510-519, 1999.

McKay, R. M. L., Villareal, T. A., and LaRoche, J.: Vertical migration by Rhizosolenia spp. (Bacillariophyceae): Implications for Fe acquisition, J. Phycol., 36, 669-674, 2000.

Medina, M. and Gómez-Moreno, C.: Interaction of ferredoxin$\mathrm{NADP}^{+}$reducatase with its substrates: optimal interaction for efficient electron transfer. Photosynth. Res., 79, 113-131, 2004.

Menden-Deuer, S. and Lessard, E. J.: Carbon to volume relationships for dinoflagellates, diatoms, and other protist plankton, Limnol. Oceanogr., 45, 569-579, 2000.

Misumi, K., Tsumune, D., Yoshida, Y., Uchimoto, K., Nakamura, T., Nishioka, J., Mitsudera, H., Bryan, F. O., Lindsay, K., Moore, J. K., and Doney, S. C.: Mechanisms controlling dissolved iron distribution in the North Pacific: A model study, 116, G03005, doi:10.1029/2010JG001541, 2011.

Nagao, S., Terashima, M., Seki, O., Takata, H., Kawahigashi, M., Kodama, H., Kim V. I., Shesterkin, V. P., Levshina, S. I., and
Makinov A. N.: Biogeochemical behavior of iron in the lower Amu River and Amur-Liman, in: Report on Amur-Okhotsk Project No. 6, Research Institute for Humanity and Nature, Japan, 41-50, 2010.

Nakatsuka, T., Fujimune, T., Yoshikawa, C., Noriki, S., Kawamura, K., Fukamachi, Y., Mizuta, G., and Wakatsuchi, M.: Biogenic and lithogenic particle fluxes in the western region of the Sea of Okhotsk: Implications for lateral material transport and biological productivity, J. Geophys. Res., 109, C09S13, doi:10.1029/2003JC001908, 2004.

Nishioka, J., Ono, T., Saito, H., Nakatsuka, T., Takeda, S., Yoshimura, T., Suzuki, K., Kuma, K., Nakabayashi, S., Tsumune, D., Mitsudera, H., Johnson, W. K., and Tsuda, A.: Iron supply to the western subarctic Pacific: Importance of iron export from the Sea of Okhotsk, J. Geophys. Res., 112, C10012, doi:10.1029/2006JC004055, 2007.

Nishioka, J., Ono, T., Saito, H., Sakaoka, K., and Yoshimura, T.: Oceanic iron supply mechanisms which support the spring diatom bloom in the Oyashio region, western subarctic Pacific, J. Geophys. Res., 116, C02021, doi:10.1029/2010JC006321, 2011.

Nishioka, J., Nakatsuka, T., Watanabe, Y. W., Yasuda, I., Kuma, K., Ogawa, H., Ebuchi, N., Scherbinin, A., Volkov, Y. N., Shiraiwa, T., and Wakatsuchi, M.: Intensive mixing along an island chain controls oceanic biogeochemical cycles, Global Biogeochem. Cy., 27, 920-929, 2013.

Nishioka, J., Nakatsuka, T., Ono, K., Volkov, Y. N., Scherbinin, A., and Shiraiwa, T.: Quantitative evaluation of iron transport processes in the Sea of Okhotsk, Prog. Oceanogr., in press, doi:10.1016/j.pocean.2014.04.011, 2014.

Obata, H., Karatani, H., and Nakayama, E.: Automated determination of iron in seawater by chelating resin concentration and chemiluminescence detection, Anal. Chem., 65, 1524-1528, 1993.

Ogi, M., Tachibana, Y., Nishio, F., and Danchenkov, M. A.: Does the fresh water supply from the Amur River flowing into the Sea of Okhotsk affect sea ice formation? J. Meteorol. Soc. Jpn, 79, 123-129, 2001.

Ohshima, K. I., Wakatsuchi, M., Fukamachi, Y., and Mizuta G.: Near-surface circulation and tidal currents of the Okhotsk Sea observed with satellite-tracked drifters, J. Geophys. Res., 107, 3195, doi:10.1029/2001JC001005, 2002.

Okunishi, T., Kishi, M. J., Ono, Y., and Yamashita, T.: A lower trophic ecosystem model including iron effects in the Okhotsk Sea. Cont. Shelf Res., 27, 2080-2098, doi:10.1016/j.csr.2007.05.007, 2007.

Orlova, T. Y., Selina, M. S., and Stonik, I. V.: Species structure of plankton microalage on the coast of the Sea of Okhotsk on Sakhalin Island, Russ. J. Mar. Biol., 30, 77-86, 2004.

Pankowski, A. and McMinn, A.: Iron availability regulates growth, photosynthesis, and production of ferredoxin and flavodoxin in Antarctic sea ice diatoms, Aquat. Biol., 4, 273-288, 2009a.

Pankowski, A. and McMinn, A.: Development of immunoassays for the iron-regulated proteins ferredoxin and flavodoxin in polar microalgae, J. Phycol., 45, 771-783, 2009b.

Parkhill, J.-P., Maillet, G., and Cullen, J. J.: Fluorescence-based maximal quantum yield for PSII as a diagnostic of nutrient stress. J. Phycol., 37, 517-29, 2001.

Raiswell, R.: Towards a global highly reactive iron cycle. J. Geochem. Expl., 88, 436-439, 2006. 
Rusch, D. B., Martiny, A. C., Dupont, C. L., Halpern, A. L., and Venter, J. C.: Characterization of Prochlorococcus clades from iron-depleted oceanic regions, Proc. Natl. Acad. Sci. USA, 107, 16184-16189, 2010.

Ryther, J. H. Photosynthesis and fish production in the sea, Science, 166, 72-76, 1969.

Sarthou, G., Timmermans, K. R., Blain, S., and Tréguer, P.: Growth physiology and fate of diatoms in the ocean: a review, J. Sea Res., 53, 25-42, doi:10.1016/j.seares.2004.01.007, 2005.

Sedwick, P. N., Marsay, C. M., Sohst, B. M., Aguilar-Islas, A. M., Lohan, M. C., Long, M. C., Arrigo, K. R., Dunbar, R. B., Saito, M. A., Smith, W. O., and DiTullio, G. R.: Early season depletion of dissolved iron in the Ross Sea polynya: Implications for iron dynamics on the Antartic continental shelf, J. Geophys. Res., 116, C12019, doi:10.1029/2010JC006553, 2011.

Shelly, K., Holland, D., and Beardall, J. Assessing nutrient status of microalgae using chlorophyll $a$ fluorescence, in: Chlorophyll $a$ fluorescence in Aquatic Sciences: Methods and Applications, Developments in Applied Phycology 4, Springer, Dordrecht, 223-235, 2011.

Sorokin, Y. I. and Sorokin, P. Y.: Production in the Sea of Okhotsk, J. Plankton Res., 21, 201-230, 1999.

Sorokin, Y. I. and Sorokin, P. Y.: Microplankton and primary production in the Sea of Okhotsk, J. Plankton Res., 24, 453-470, 2002.

Strzepek, R. F. and Harrison, P. J.: Photosynthetic architecture differs in coastal and oceanic diatoms, Nature, 431, 689-692, 2004.

Sugie, K., Nishioka, J., Kuma, Volkov, Y. N., and Nakatsuka, T.: Availability of particulate Fe to phytoplankton in the Sea of Okhotsk, Mar. Chem., 152, 20-31, 2013.

Sunda, W. G. and Huntsman, S. A.: Iron uptake and growth limitation in oceanic and coastal phytoplankton, Mar. Chem., 189-206, 1995.

Sunda, W. G. and Huntsman, S. A.: Interrelated influence of iron, light and cell size on marine phytoplankton growth, Nature, 389392, 1997.

Suzuki, K., Liu, H., Saino, T., Obata, H., Takano, M., Okamura, K., Sohrin, Y., and Fujishima, Y.: East-west gradients in the photosynthetic potential of phytoplankton and iron concentration in the subarctic Pacific Ocean during early summer, Limnol. Oceanogr., 47, 1581-1594, 2002.

Suzuki, K., Saito, H., Isada, H., Hattori-Saito, A., Kiyosawa, H., Nishioka, J., McKay, R. M. L., Kuwata, A., and Tsuda, A: Community structure and photosynthetic physiology of phytoplankton in the northwest subarctic Pacific during an in situ iron fertilization experiment (SEEDS-II), Deep-Sea Res. Pt. II, 56, $2733-$ 2744, 2009.

Suzuki, K., Kuwata, A., Yoshie, N., Shibata, A., Kawanobe, K., and Saito, H.: Population dynamics of phytoplankton, heterotrophic bacteria, and viruses during the spring bloom in the western subarctic Pacific, Deep-Sea Res. Pt. I, 58, 575-589, 2011.
Suzuki, R. and Ishimaru, T.: An improved method for the determination of phytoplankton chlorophyll using N,Ndimethylformamide, J. Oceanogr., 46, 190-194, 1990.

Takao, S., Iida, T., Isada, T., Saitoh, S., Hirata, T., and Suzuki, K.: Bio-optical properties during the summer season in the Sea of Okhotsk, Prog. Oceanogr., in press, doi:10.1016/j.pocean.2014.04.010, 2014.

Timmermans, K. R., van der Wagt, B., and de Baar, H. J. W.: Growth rates, half saturation constants, and silicate, nitrate, and phosphate depletion in relation to iron availability for large, openocean diatoms from the Southern Ocean, 49, 2141-2151, 2004.

Tomas, C. R.: Identifying Marine Phytoplankton, Academic Press, San Diego, USA, 1997.

Twining, B. S. and Baines, S. B.: The trace metal composition of marine phytoplankton, Annu. Rev. Mar. Sci., 5, 191-215, 2013.

Van Heukelem, L. and C. S. Thomas: Computer-assisted highperformance liquid chromatography method development with applications to the isolation and analysis of phytoplankton pigments, J. Chromatogr., 910, 31-49, 2001.

Vidussi, F., Claustre, F., Manca, B. B., Luchetta, A., Marty, J.-C.: Phytoplankton pigment distribution in relation to upper thermocline circulation in the eastern Mediterranean Sea during winter, J. Geophys. Res., 106, 19939-19956, 2001.

Vesk, M. and Jeffrey, S. W.: Effect of blue-green light on photosynthetic pigments and chloroplast structure in unicellular marine algae from six classes, J. Phycol., 13, 280-288, 1977.

Welshmeyer, N. A.: Fluorometric analysis of chlorophyll $a$ in the presence of chlorophyll $b$ and phaeopigments, Limnol. Oceanogr., 39, 1985-1992, 1994.

Whitney, L. P., Lins, J. J., Hughes, M. P., Wells, M. L., Chappell, P. D., and Jenkins, B. D.: Characterization of putative iron responsive genes as species-specific indictors of iron stress in Thalassiroid diatoms, Front. Microbiol., 2, 1-14, 2011.

Yagi, M. and Yasuda, I.: Deep intense vertical mixing in the Bussol' Strait, Geophys. Res. Lett., 39, L01602, doi:10.1029/2011GL050349, 2012.

Yoshimura, T. Nishioka, J., and Nakatsuka, T.: Iron nutritional status of the phytoplankton assemblage in the Okhotsk Sea, DeepSea Res. Pt. I, 57, 1454-1464, 2010.

Zapata, M., Fraga, S., Rodriguez, F., and Garrido, J. L.: Pigmentbased chloroplast types in dinoflagellates. Mar. Ecol. Prog. Ser., 465, 33-52, 2012.

Zurbriggen, M. D., Tognetti, and V. B., Carrillo, N.: Stressinducible flavodoxin from photosynthetic microorganisms. The mystery of flavodoxin loss from the plant genome, IUBMB Life, 59, 355-360, 2007. 